\title{
Epoxides-is there a human health problem?
}

\author{
MARGARET M MANSON \\ From the MRC Toxicology Unit, MRC Laboratories, Carshalton, Surrey SM5 4EF, UK
}

ABSTRACT The purpose of this review is to consider whether epoxides represent a hazard to human health. Possible means of occupational and non-occupational exposure are discussed with reference to the production and uses of industrially important compounds and other epoxides, such as naturally occurring plant and fungal products. In addition to epoxides themselves, unsaturated compounds that may be metabolised in vivo to epoxides are included, since this appears to be a further important means of exposure. The toxicology, in particular carcinogenicity and mutagenicity, is discussed, along with a brief outline of the biochemistry such as metabolism, binding to cell constituents, and DNA repair mechanisms. The question of interactions between different epoxides in vivo is also raised.

During the past 30 years there has been an ever increasing number of reports on the toxicity, mutagenicity, and carcinogenicity of epoxides. Much of the current interest in these compounds has been generated by the finding that an epoxide seems to be the ultimate carcinogenic metabolite for several polyaromatic hydrocarbons. But even from the earliest studies it was realised that the same properties that made epoxides so useful in industrial processes could also pose potential hazards for biological systems. And yet it is still unclear exactly how big a problem they are in terms of human health.

Epoxides are ubiquitous - they occur naturally, in industry, the environment, and in vivo as metabolites in certain biochemical pathways. Several of these compounds are quite toxic, a few even carcinogenic, at least in animals, but because epoxides vary greatly in reactivity and molecular geometry they are not all equally hazardous.

In this review the term epoxide refers to any molecule containing the three-membered ring

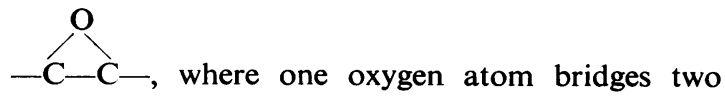
carbon atoms. The nomenclature is confusing, ${ }^{1}$ but the compounds are referred to here by their most commonly used names. ${ }^{2} 3$

Epoxides can be solids, liquids, or gases. Ethylene

Received 20 February 1979

Accepted 23 April 1980 oxide, the simpiest aliphatic epoxide, is a gas whose vapours are explosive in mixtures with air, but can be inactivated by mixing with $\mathrm{CO}_{2}$ or fluorocarbons (Freon). Under certain conditions ethylene oxide will polymerise to a liquid or solid. Propylene oxide is a liquid with a low boiling point, so that it can occur as a gas with properties similar to ethylene oxide. Some epoxides are liquids with much higher boiling points, such as epichlorohydrin, diepoxybutane, and styrene oxide, while glycidyl oleate is an oil. 9-10-Epoxystearic acid and fusarenon-X, two naturally occurring epoxides, are solids. The most important characteristics of epoxides arise from their electrophilic and lipophilic nature and the reactivity of the epoxide ring. Ring-opening reactions entail attack by a nucleophile, such as $\mathrm{NH}_{2}, \mathrm{OH}^{-}, \mathrm{Cl}^{-}$, or a thiol-in fact reactions with $\mathrm{OH}^{-}$and $\mathrm{S}^{-}$ groups, both enzymically and non-enzymically, are two of the major in-vivo mechanisms for eliminating these compounds.

The emphasis of this review is more towards the aliphatic compounds, as these are industrially the most important epoxides and since there are several comprehensive reviews on the polyaromatic hydrocarbons and their epoxides (arene oxides)..$^{4-9}$

\section{Occurrence and exposure —epoxides}

Epoxides are produced industrially in vast quantities. The reactivity of the epoxy group makes them particularly useful as alkylating or cross-linking agents. The most widely used are the small aliphatic com- 
Table 1 Industrial uses and production figures-epoxides ${ }^{1011}$

\begin{tabular}{|c|c|c|}
\hline Epoxide & Industrial uses & $\begin{array}{l}\text { Approximate quantity produced } \\
\text { (country, year) }\end{array}$ \\
\hline Diepoxybutane & $\begin{array}{l}\text { Curing of polymers; cross-linking textile fibres; prevention of microbial } \\
\text { spoilage; chemical intermediate }\end{array}$ & \\
\hline Diglycidyl resorcinol ether & $\begin{array}{l}\text { Liquid epoxy resin; reactive diluent in production of other epoxy resins; } \\
\text { curing of polysulphide rubber }\end{array}$ & $5000 \mathrm{~kg}$ (Japan, 1975) \\
\hline Epichlorohydrin $(\mathrm{ECH})$ & $\begin{array}{l}\text { Production of synthetic glycerin; preparation of unmodified epoxy resins, } \\
\text { ECH elastomers, glycidyl ethers, modified epoxy resins, wet-strength resins } \\
\text { for the paper industry, water treatment resins; cross-linking starch in food; } \\
\text { paint solvent }\end{array}$ & $\begin{array}{l}\left.156.5 \times 10^{6} \mathrm{~kg} \text { (USA, } 1973\right) \\
41 \times 10^{6} \mathrm{~kg}(\text { Japan, } 1974) \\
\text { No longer produced in UK }\end{array}$ \\
\hline Epoxidised soya-bean oil & Stabiliser and plasticiser in PVC industry & $46.5 \times 10^{6} \mathrm{~kg}(\mathrm{USA}, 1974)$ \\
\hline Epoxy resins & $\begin{array}{l}\text { Surface coatings; castings and pottings for tooling and encapsulating } \\
\text { electronic circuits; adhesives, especially in metal-to-metal bonding; textile } \\
\text { treating agents to improve wearability and crease-resistance; laminating } \\
\text { especially for structural use in aircraft }\end{array}$ & $\begin{aligned} 99 & \times 10^{6} \mathrm{~kg}(\text { USA, } 1973)^{12} \\
113 & \times 10^{6} \mathrm{~kg}(\text { USA, 1974) }\end{aligned}$ \\
\hline Ethylene oxide & $\begin{array}{l}\text { Production of ethylene glycol used mainly in antifreeze products; } \\
\text { polyethylene terephthalate polyester fibre and film production; manufacture } \\
\text { of non-ionic surface active agents, diethylene glycol, triethylene glycol, } \\
\text { ethanolamines, choline and choline chloride, and other organic chemicals; } \\
\text { fungicide for treating books, and dental, pharmaceutical, medical, and } \\
\text { scientific equipment, drugs, leather, motor oil, paper, soil, bedding for } \\
\text { experimental animals, clothing, furs, furniture, and vehicles; sterilisation of } \\
\text { foodstuffs; to accelerate maturing of tobacco leaves }\end{array}$ & $\begin{array}{l}865 \times 10^{6} \mathrm{~kg} \text { (Europe, 1972) } \\
415 \times 10^{6} \mathrm{~kg}(\text { (Japan, 1974) } \\
119.5 \times 10^{6} \mathrm{~kg} \text { (UK, previously) } \\
1892 \times 10^{6} \mathrm{~kg} \text { (USA, 1973) } \\
1896 \times 10^{6} \mathrm{~kg} \text { (USA, 1976) } \\
2005 \times 10^{6} \mathrm{~kg} \text { (USA, 1977) }\end{array}$ \\
\hline Glycidaldehyde & $\begin{array}{l}\text { Cross-linking agent in finishing of wool; oil tanning and fat liquoring of } \\
\text { leather and surgical sutures; protein insolubilisation, tested as a vapour } \\
\text { phase disinfectant (inactivates foot and mouth virus) }\end{array}$ & $\begin{array}{l}\text { No evidence of commercial } \\
\text { production or use in USA }\end{array}$ \\
\hline Propylene oxide & $\begin{array}{l}\text { Production of polyether polyols for polyurethane foams; polypropylene } \\
\text { glycol for unsaturated polyester resins; conversion to dipropylene glycol, } \\
\text { glycolethers, and synthetic glycerin; fumigant for materials from plastic } \\
\text { medical instruments to food }\end{array}$ & $\begin{array}{c}903 \times 10^{6} \mathrm{~kg}(\text { Europe, 1973) } \\
131 \times 10^{6} \mathrm{~kg}(\text { Japan, 1974) } \\
<50.8 \times 10^{6} \mathrm{~kg}(\text { UK, 1977) } \\
796 \times 10^{6} \mathrm{~kg}(\text { USA, 1973) } \\
812 \times 10^{6} \mathrm{~kg}(\text { USA, 1976) } \\
862 \times 10^{6} \mathrm{~kg}(\text { USA, 1977) }\end{array}$ \\
\hline Styrene oxide & $\begin{array}{l}\text { Diluent in epoxy resins; preparation of agricultural and biological } \\
\text { chemicals, cosmetics, surface coatings; treatment of textiles and fibres; } \\
\text { production of phenyl ethyl alcohol }\end{array}$ & $\begin{array}{l}100 \times 10^{3} \mathrm{~kg}(\text { Japan, pre-1976) } \\
\text { Smaller quantities are now being } \\
\text { produced }\end{array}$ \\
\hline Vinyl cyclohexene dioxide & $\begin{array}{l}\text { Reactive diluent for other diepoxides and for epoxy resins derived from } \\
\text { bisphenol } \mathrm{A} \text { and } \mathrm{ECH} \text {; chemical intermediate }\end{array}$ & \\
\hline
\end{tabular}

Table lists the main industrial epoxides and some of their uses, past and present. Production figures (not available for all the compounds) give an idea of the annual output for particular countries over past ten years.

pounds-ethylene oxide, propylene oxide, epoxybutane, and epichlorohydrin-and the compounds used in the epoxy resin industry, such as the glycidyl ethers. Table 1 indicates the various uses to which epoxides have been put and their production figures. Tanaka et al $^{1}$ have compiled a list of epoxides used in the epoxy resin industry along with their manufacturers.

Although a few are useful as end products-for example, as sterilising agents - they are most valuable as intermediates and as stabilisers. As intermediates they are used to manufacture surface active agents, special solvents, synthetic resins, cements, adhesives, and fine chemicals. The largest use of ethylene oxide is in the production of ethylene glycol for antifreezean estimated $67 \%$ of the total in Japan in $1974 .{ }^{10}$ In the synthesis of epoxy resins epichlorohydrin is a principal epoxidising agent.

Many commercial products, such as polyvinyl chloride (PVC) and trichloroethylene tend to degrade slowly with the evolution of $\mathrm{HCl}$. However, the addition of very small amounts (often less than $1 \%$ ) of various epoxy compounds, usually in combination with other classes of compounds, prevents this. ${ }^{13} 14$ The stabilisation mechanism is not well understood, but the role of acid acceptor is generally ascribed to the epoxide. There are many patents for using epoxides as stabilisers, but probably only a few of these have found commercial application. One brand of technical grade trichloroethylene is stabilised with $0.22 \%$ epichlorohydrin and $0.20 \%$ epoxybutane. ${ }^{15}$ Epoxidised soyabean oil is used at levels of $1.5-3.0 \%$ as a heat and light stabiliser for many PVC formulations, and at higher concentrations as a plasticiser in PVC used in cars, furniture, floor coverings, packaging films, and coatings for wire. The use of epoxy compounds as polymer stabilisers and plasticisers has been reviewed by Port $^{16}$ and the stabilisation of 1,1,1-trichloroethane, trichloroethylene, and tetrachloroethylene was discussed by Szczeszek. ${ }^{17}$

\section{OCCUPATIONAL EXPOSURE}

Because of the vast quantities handled, by far the highest risk of exposure to epoxides will be in the work place where these compounds are produced or used.

Propylene oxide and in particular ethylene oxide 
are widely used as sterilising agents (table 1). Despite other advantages, the time for sterilisation and aeration with these gases is much longer than for some other methods and has been described as more difficult to control, ${ }^{18}$ thus increasing the likelihood of exposure. ${ }^{19}$

Workers come into contact with epoxide stabilisers in chemicals that they handle in large quantities-for example, in trichloroethylene used for degreasing machinery and drycleaning.

Although there is little information on the number of people occupationally exposed or the concentrations handled, production figures show that many employees may be affected in many industrial situations, and that the concentrations of chemicals may be significant for chronic, if not acute, exposure.
Threshold limit values have been set for several epoxides ${ }^{20}$ but even if these values, which vary from country to country, were adhered to, they have usually been set on the basis of irritant properties and other obvious clinical symptoms, with little consideration for potentially more serious long-term toxic effects.

Exposure may be reduced by proper ventilation, protective clothing, respirators, alarm systems, and personnel monitoring. Segal et $a l^{21}$ have described a personal monitoring badge capable of detecting direct alkylating agents such as diepoxybutane and glycidaldehyde in the lower ppb range. The toxicity, hazards, and safe handling of materials used in the epoxy resin industry have been discussed by Borgstedt and Hine. ${ }^{22}$

Table 2 Examples of non-occupational exposure to epoxides

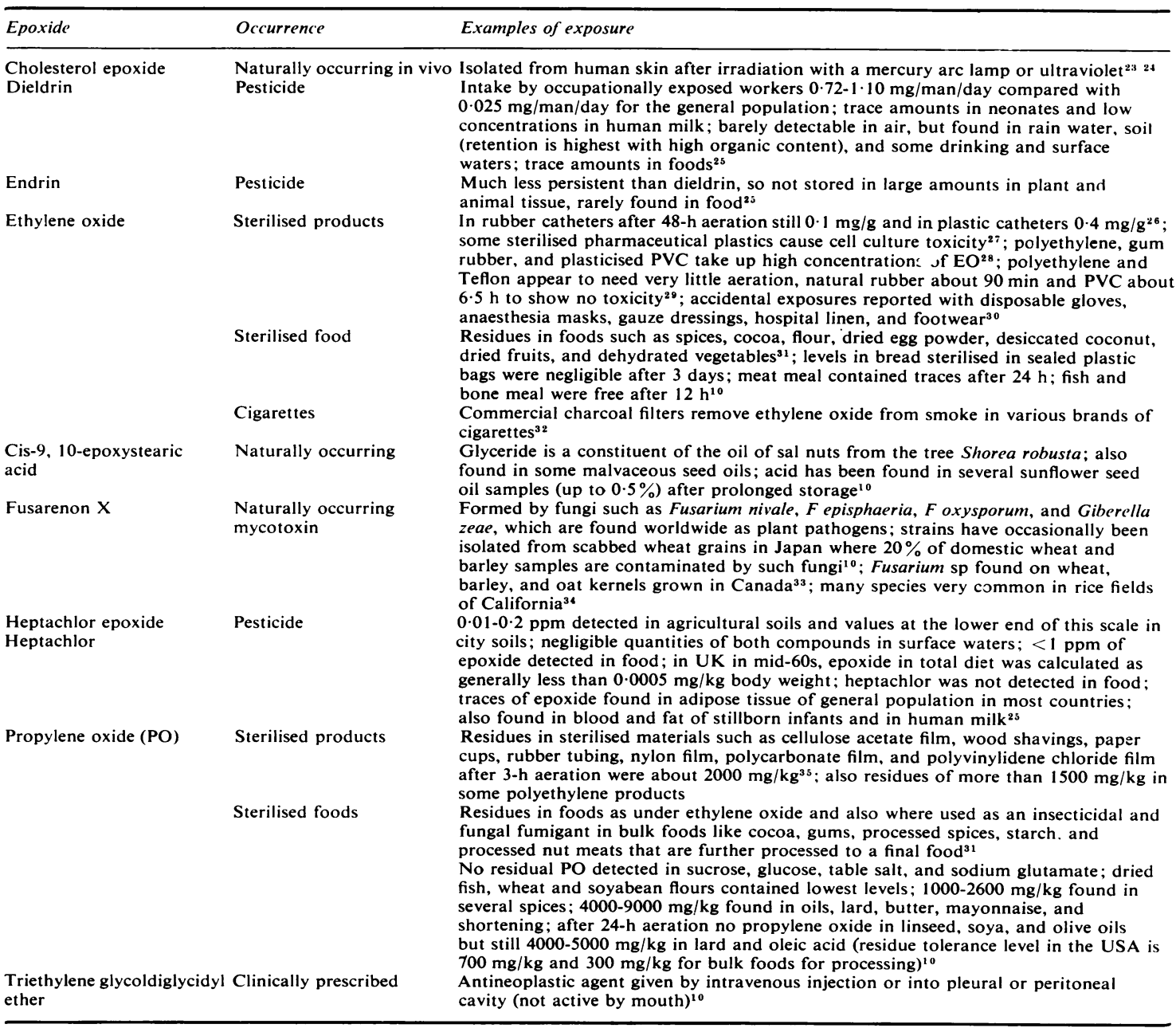


NON-OCCUPATIONAL AND CLINICAL

\section{EXPOSURE}

Non-occupational and clinical exposure will generally be to much lower levels than in industrial settings but may be more difficult to identify (table 2 ). The most obvious non-occupational exposure occurs as a direct result of the industrial use of epoxides-for example, after accidental release of large quantities into the atmosphere or from continuous low levels escaping from the factory. The possible occurrence of epoxides in air pollution has been discussed by Kotin and Falk ${ }^{36}$ and Van Duuren. ${ }^{37}$ Members of a worker's family may be exposed if he returns home without washing or changing his clothes.

The use of sterilised products such as wrappings, tubings, medical equipment, and food, which contain residual amounts of ethylene oxide or propylene oxide, also results in exposure. Whitbourne and West $^{18}$ showed that although many materials can absorb up to $30000 \mathrm{ppm}$ of the gas during sterilisation, with adequate aeration before use the gas was eluted from almost all of the hundreds of materials tested. Nonetheless, there are still many reports of accidental exposure to residual gas in sterilised items. ${ }^{30}$ An additional problem with foods is the formation of glycol or halohydrin residues. Since gaseous sterilisation requires the presence of some moisture to be effective, glycol formation would seem inevitable. Both ethylene oxide and propylene oxide also combine with chlorine from the natural inorganic chloride content of food, forming the corresponding chlorohydrins. ${ }^{27}$ These chlorohydrins are non-volatile and chemically unreactive as they persist through normal food-processing conditions. They are, however, toxic and mutagenic. ${ }^{38} 39$

A reasonably efficient way of contaminating air, soil, water, and food, and therefore eventually man is by the widespread use of non-biodegradable pesticides. Some of these are epoxides or compounds that are readily converted to epoxides in the soil, such as aldrin and its epoxide dieldrin, and heptachlor and heptachlor epoxide. The use of some of these compounds, however, is now restricted or banned in many countries.

The formation of epoxides as a result of heating certain vegetable oils in air during cooking has also been reported. 4041

Epoxides occur naturally in some plant oils used in the food industry, and as mycotoxins. Triglycerides containing epoxy fatty acids are well distributed in seed oils of plant families such as the Compositae, Dipsaceae, Euphorbiaceae, and Malvaceae. ${ }^{10}$ Mycotoxin epoxides, such as the 12,13epoxytrichothecenes, produced by various species of Fusarium, Myrothecium, Trichoderma, and Cephalosporium, are found in foodstuffs for animal and human consumption. ${ }^{42} 43$ Nearly all the trichothecenes show high biological activity. In a review of steroid epoxides in biological systems, Kadis ${ }^{9}$ listed the naturally occurring epoxides that may be involved in steroid metabolism.

Several epoxides have been tested as anticancer agents because of their cytotoxic effects, 244 and one that has been used clinically is triethylene glycol diglycidyl ether. ${ }^{10}$

\section{Occurrence and exposure—potential epoxides}

In addition to the industrial and other environmental epoxides already discussed there is a growing awareness of their role as metabolic intermediates. When an unsaturated compound enters the body, one means of making it more soluble and therefore more readily excretable is to hydroxylate it by first adding an oxygen across the double bond to form an epoxide ring. This metabolic route has now been shown for many polyaromatic hydrocarbons, such as benzo(a)pyrene, benz(a,h)anthracene, and phenanthrene, and there is growing evidence that it occurs in many of the simpler aliphatic molecules such as vinyl chloride and trichloroethylene. ${ }^{45}$ In most cases the epoxide metabolite appears to be much more toxic than the parent compound. Therefore, for completeness, it is also necessary to consider exposure to potential epoxides.

\section{PRODUCTION AND USES}

Table 3 lists a few examples of industrial unsaturated compounds that may be metabolised to epoxides in vivo, along with their uses and production figures. As with epoxides themselves, vast quantities of these potential epoxides are used in a wide range of industrial processes, again affecting many workers.

\section{OCCUPATIONAL EXPOSURE}

Styrene, which can be metabolised to styrene oxide, is one of the most widely used raw materials for plastics. Barsotti et al $^{48}$ reported levels of almost $200 \mathrm{ppm}$ during polymerisation processes and 20-50 ppm for other processes. It has been estimated that about one-tenth of the styrene used during the curing of polyester resins evaporates into the atmosphere. Peak levels during laminating may exceed 500 ppm. ${ }^{47}$ Heating commercial polystyrene, during cutting for example, may give off styrene in amounts from several hundred to a few thousand ppm. 4950

The National Institute for Occupational Safety and Health, USA, estimated that 282653 workers might be exposed in various industries in the United States to significant amounts of trichloroethylene. In Sweden some 10000 workers have been "more or 
Table 3 Industrial uses and production figures-potential epoxides 1011254647

\begin{tabular}{|c|c|c|}
\hline Potential epoxides & Industrial uses & $\begin{array}{l}\text { Approximate quantity produced } \\
\text { (country, year) }\end{array}$ \\
\hline Acrylonitrile & Synthetic rubber, plastics, organic synthesis & $\begin{array}{l}689 \times 10^{6} \mathrm{~kg}(\text { USA, 1976) } \\
744 \times 10^{6} \mathrm{~kg}(\text { USA, 1977) }\end{array}$ \\
\hline Aldrin & Insecticide for crops, termite control & $4.5 \times 10^{6} \mathrm{~kg}(\mathrm{USA}, 1971)$ \\
\hline Benzene & $\begin{array}{l}\text { Chemical intermediate in manufacture of cyclohexane, ethylbenzene, phenol, } \\
\text { maleic anhydride, detergent alkylate, aniline, dichlorobenzenes, DDT; solvent } \\
\text { in paint manufacture and rubber cements }\end{array}$ & $\begin{array}{l}4812 \times 10^{6} \mathrm{~kg}(\text { USA, 1976) } \\
5102 \times 10^{6} \mathrm{~kg}(\text { USA, 1977) }\end{array}$ \\
\hline Butadiene (1,3-) & Rubber industry & $\begin{array}{l}1474 \times 10^{6} \mathrm{~kg}(\text { USA, 1976) } \\
1447 \times 10^{6} \mathrm{~kg}(\text { USA, 1977) }\end{array}$ \\
\hline Ethylene & $\begin{array}{l}\text { Fuel in welding; anaesthetic; added to manufactured gas as an illuminant: } \\
\text { conditioning and colouring of fruits and blanching of vegetables }\end{array}$ & $\begin{array}{r}9991 \times 10^{6} \mathrm{~kg}(\text { USA, 1976) } \\
11 \times 10^{9} \mathrm{~kg} \text { (USA, 1977) }\end{array}$ \\
\hline Heptachlor & Insecticide for crops (use now restricted) & $2.7 \times 10^{6} \mathrm{~kg}(\mathrm{USA}, 1971)$ \\
\hline Propylene & Chemical intermediate & $\begin{array}{l}4426 \times 10^{6} \mathrm{~kg}(\text { USA, 1976) } \\
5696 \times 10^{6} \mathrm{~kg}(\text { USA, 1977) }\end{array}$ \\
\hline Styrene & $\begin{array}{l}\text { Manufacture of a wide variety of elastomers and plastics; solvent and } \\
\text { crosslinking agent for polyester resins }\end{array}$ & $\begin{array}{l}2844 \times 10^{6} \mathrm{~kg}(\mathrm{USA}, 1973)^{46} \\
2032 \times 10^{6} \mathrm{~kg}(\mathrm{USA}, 1975)^{47} \\
2857 \times 10^{6} \mathrm{~kg}(\mathrm{USA}, 1976) \\
3093 \times 10^{6} \mathrm{~kg}(\mathrm{USA}, 1977)\end{array}$ \\
\hline Trichloroethylene & $\begin{array}{l}\text { Vapour degreasing of fabricated metal parts; chain terminator for PVC } \\
\text { production; drycleaning; solvent in textile industry; extractant in food } \\
\text { processing (decaffeinated coffee-now discontınued in USA); chemical } \\
\text { intermediate; anaesthetic }\end{array}$ & $\begin{aligned} 9 & \times 10^{6} \mathrm{~kg}(\text { Japan, 1974) } \\
193 & \times 10^{6} \mathrm{~kg}(\text { USA, 1974) }\end{aligned}$ \\
\hline Vinyl chloride & $\begin{array}{l}\text { Production of vinyl chloride homopolymer and copolymer resin; production } \\
\text { of methyl chloroform; additive to specialty coatings; component of certain } \\
\text { propellant mixtures in pesticides and hair sprays (now discontinued); in the } \\
\text { past as a refrigerant, extraction solvent for heat-sensitive materials, } \\
\text { intermediate in synthesis of sulpha drugs }\end{array}$ & $\begin{array}{l}2.6 \times 10^{9} \mathrm{~kg}(\text { USA, 1974), } \\
2.6 \times 10^{9} \mathrm{~kg} \text { (USA, 1976) } \\
2.6 \times 10^{9} \mathrm{~kg} \text { (USA, 1977) } \\
7.0 \times 10^{9} \mathrm{~kg}(\text { expected } \\
\text { worldwide, } 1978)\end{array}$ \\
\hline
\end{tabular}

Table lists a few examples of unsaturated compounds, which are widely used in industry, and for which there is evidence to suggest that they are metabolised to epoxides in vivo.

less constantly" exposed to trichloroethylene during the past 20 years of its production and use. ${ }^{51}$ About 5000 medical, dental, and hospital personnel in the United States may be routinely exposed when trichloroethylene is used as an anaesthetic. ${ }^{52}$ The range of concentrations in an operating theatre under routine working conditions was found to be $5 \cdot 5-550 \mathrm{mg} / \mathrm{m}^{3}(1-103 \mathrm{ppm})$ near the anaesthetist, and $1 \cdot 6-8 \mathrm{mg} / \mathrm{m}^{3}(0 \cdot 3-1 \cdot 5 \mathrm{ppm})$ near the surgeon. ${ }^{53} 54$ The anaesthetic grade of trichloroethylene, unlike the technical grade solvent, does not appear to be stabilised by epoxides.

Vinyl chloride is another potential epoxide, and world-wide employment in the monomer and PVC industries is over 70000 workers. Those employed in industries making use of PVC are believed to number millions. ${ }^{55}$ Possible means of exposure during production of PVC have been described. ${ }^{56}$ Of all the compounds mentioned in this review, however, the hazards of vinyl chloride are probably the best recognised.

\section{NON-OCCUPATIONAL AND CLINICAL EXPOSURE (see table 4)}

Again the most obvious environmental exposure occurs as a direct result of industrial production and use. Large populations, living in close proximity to industries such as those manufacturing vinyl chloride and PVC, may be at risk. One study in Los Angeles County in 1966 estimated that hydrocarbon emissions into the atmosphere from organic solvent usage comprised more than $20 \%$ of all hydrocarbon emissions. Of the estimated 590 tons emitted each day, 88 tons were attributed to halogenated hydrocarbons, including trichloroethylene and vinyl chloride. 57

More general atmospheric pollution results from traffic exhaust, various other types of combustion, cigarette smoke, and the use of aerosols. Benzo(a) pyrene is an obvious example of a potentially toxic air pollutant that is metabolised to an epoxide. Human exposure to polyaromatic hydrocarbons has been reviewed by Bridbord et al. 58

The general population may be exposed to several potential epoxides in various consumer products-for example, to styrene or vinyl chloride leaching into food from plastic containers. Lloyd et $a l^{52}$ have listed American consumer goods containing trichloroethylene. Cigarettes are also a source of some compounds that can be metabolised to epoxides.

When taking clinically prescribed drugs, an individual may be receiving a deliberate daily dose of $\mathrm{mg}$ quantities of a toxic chemical, and the risks of the drug must be weighed against the benefits. Many clinically used drugs are now known to be metabolised to epoxides, and drugs with structural features prone to metabolic oxidation are abundant (table 4). The formation of these epoxides per se may not be a problem in terms of toxicity, mutagenicity, or carcinogenicity, but, as will be discussed in more detail in a later section, may be significant 
Table 4 Examples of non-occupational exposure to potential epoxides

\begin{tabular}{|c|c|c|}
\hline Potential epoxide & Occurrence & Examples of exposure \\
\hline Aflatoxin & $\begin{array}{l}\text { Naturally occurring } \\
\text { mycotoxin }\end{array}$ & $\begin{array}{l}\text { Common contaminants of feedstuffs, especially peanuts, peanut meal, and grain crops during } \\
\text { harvesting and storage; responsible for outbreaks of mycotoxicosis in many species of animals and } \\
\text { in humans } 5\end{array}$ \\
\hline Aldrin & Pesticide & $\begin{array}{l}\text { Epoxidised to dieldrin in soil and conversion also occurs readily in plants and animals; very small } \\
\text { amounts found in soil and water, but rarely found in foods because of epoxidation }{ }^{25} \text {; application of } \\
\text { up to } 25 \mathrm{lb} / \text { acre of corn soil resulted in retention of } 10 \% \text {, mainly as dieldrin, after } 4 \mathrm{yr}^{60}\end{array}$ \\
\hline Benzo(a)pyrene & $\begin{array}{l}\text { Atmospheric } \\
\text { Cigarettes }\end{array}$ & $\begin{array}{l}\text { Constituent of automobile exhaust, city smog and charcoal-cooked foods }{ }^{61} ; 2000 \text { tons/day put into } \\
\text { the air in the USA } \\
0 \cdot 2-12 \cdot 2 \mu \mathrm{g} / 100 \text { cigarettes }{ }^{62-64}\end{array}$ \\
\hline Clinical drugs & Prescribed & $\begin{array}{l}\text { Drugs for which epoxide metabolites have been reported: allobarbital, secobarbital, alphenal, } \\
\text { protriptyline, cyclobenzaprine, carbamazepine, cyproheptadine, phylloquinone or vitamin } \mathrm{K}_{1} \text {, some } \\
\text { contraceptive steroids } \\
\text { Drugs for which terminal metabolites indicate metabolism via an epoxide: diethylstilboestrol, } \\
\text { diphenylhydantoin, phensuximide, phenobarbital, mephobarbital, metaqualone, lorazepam, } \\
\text { imipramine, acetanilide }{ }^{65}\end{array}$ \\
\hline Styrene & Consumer products & $\begin{array}{l}\text { Various plastic items, eg polystyrene foam cups or food containers can contain } 80-3600 \mathrm{ppm} \text {, with } \\
0.02-35 \mathrm{ppm} \text { leaching into water, } 50 \% \text { alcohol and yogurt }\end{array}$ \\
\hline Trichloroethylene & $\begin{array}{l}\text { Consumer products } \\
\text { Anaesthetic }\end{array}$ & $\begin{array}{l}\text { List of American goods containing TCE } \\
\text { Maximum of } 60000 \text { patients a year }{ }^{67}\end{array}$ \\
\hline Vinyl chloride & $\begin{array}{l}\text { Water } \\
\text { Consumer products } \\
\text { Cigarettes }\end{array}$ & $\begin{array}{l}\text { Total escaping to atmosphere in USA is } 100 \times 10^{6} \mathrm{~kg} / \mathrm{yr} \text {; more than } 1 \mathrm{ppm} \text { less than } 10 \% \text { of the } \\
\text { time in residential areas close to plants; maximum concentration } 33 \mathrm{ppm} \text { at } 0.5 \mathrm{~km} \text { from centre of } \\
\text { plant; as a propellant in aerosols (now discontinued), a } 30-\mathrm{sec} \text { burst could give an air concentration } \\
\text { of } 400 \mathrm{ppm} \text { for several hours } \\
\text { Detected in some municipal water supplies } 6869 \\
\text { Usually } 1-5 \mathrm{ppm} \text {, but can be as high as } 20 \mathrm{ppm} \text {, found in a wide variety of foodstuffs packed in } \\
\text { PVC containers } 71 \\
\text { Very low concentrations (up to } 30 \mathrm{ppb} \text { ) measured in cigarette smoke }\end{array}$ \\
\hline
\end{tabular}

when more than one epoxide is present at the same time. As already mentioned trichloroethylene is used as an anaesthetic so that a few patients are exposed for a relatively short time to a high dose of this potential epoxide.

Aflatoxins are produced by fungi of the genus Aspergillus and are common contaminants of feedstuffs. Aflatoxin $\mathrm{B}_{1}$ (one of the most potent hepatocarcinogens known) is an example of a naturally occurring fungal constituent that is not itself an epoxide, but for which there is some evidence to suggest that it may be metabolised via this intermediate. ${ }^{73-76}$ Although aflatoxin $\mathbf{B}_{1}-2,3$-epoxide is a likely candidate for the carcinogenic or acutely toxic lesion or both, there are still several reservations about this hypothesis. ${ }^{77}$

Clearly, non-occupational exposure to both epoxides and their precursors, mainly by inhalation and ingestion, varies enormously according to several factors affecting the individual and his environment, and total exposure from several sources could be quite extensive.

\section{Toxicology}

The toxicology and pharmacology for most epoxides is far from fully investigated, and there is little biochemical information on the mechanisms of toxicity, in particular of the type that allows predictions to be made for new compounds.

Absorption through the skin, inhalation, or ingestion can lead to a wide range of toxic effects in both man and experimental animals, including irritation of surface tissues; sensitisation; changes in liver function, in the circulating blood, and in bone marrow; mutagenicity; and carcinogenicity.

\section{CARCINOGENICITY}

Because of their strong electrophilic reactivity and the fact that they are alkylating agents, epoxides have been considered for carcinogenicity. As early as 1950 , Boyland ${ }^{78}$ suggested that the series of metabolic phenols and dihydrodiols formed from polyaromatic hydrocarbons might be secondary preducts of metabolically formed epoxides and that these epoxides might be intermediate in tumour production. Several epoxides have been tested, and some of them have given positive results in animal experiments. Results for many compounds are inconclusive, however, either because of inadequacies in experimental design or conflicting data. There are also quite a few epoxides for which results are negative. Therefore, apart from grouping together those that give consistently positive results (table $5 \mathrm{a}$ ), no attempt has been made to divide the other tested epoxides into carcinogens or non-carcinogens (table 5b). Arene oxides are not included as the publications in this area are too vast. Elegant studies now implicate $7 \beta, 8 \alpha$-dihydroxy-9a,10a-epoxy7,8,9,10-tetrahydrobenzo(a)pyrene as a major ultimate mutagenic and carcinogenic metabolite of benzo(a)pyrene. ${ }^{100-105}$ Cavalieri et al ${ }^{106}$ have listed some polycyclic compounds whose carcinogenicity may be mediated by an epoxide. 
The conclusions drawn must be qualified by consideration of such variables as species, strain, sex, dose, route of administration, and vehicle, and allowances made for the possibility of a long latent period. Also there is still no reliable method for extrapolating results from animal experiments to man. With all the compounds that Van Duuren's group found to be carcinogenic, high doses normally had to be given to produce significant tumour response, implying that they are weak carcinogens (see table 5 for refs). He considered that perhaps because of their high reactivity they are readily degraded in vivo and do not reach target sites in organs remote from the site of treatment, even when given in high doses.
There is no conclusive evidence for the development of cancer in man as a result of exposure to epoxides per se, although recently a warning was issued by the International Federation of Chemical Energy and General Workers' Union in Geneva, linking ethylene oxide with leukaemia. This warning followed a report by Hogstedt et al ${ }^{107}$ describing three cases of leukaemia and a generally higher incidence of cancer in a relatively small group of workers exposed to several chemicals including ethylene oxide.

Any hazard due to epoxy resins would most likely stem from contact with the skin. Hine et al ${ }^{93} \mathrm{com}$ mented that cancers of the skin are rarely produced by single contact and there is invariably a long latent

Table 5 Epoxides tested for carcinogenicity

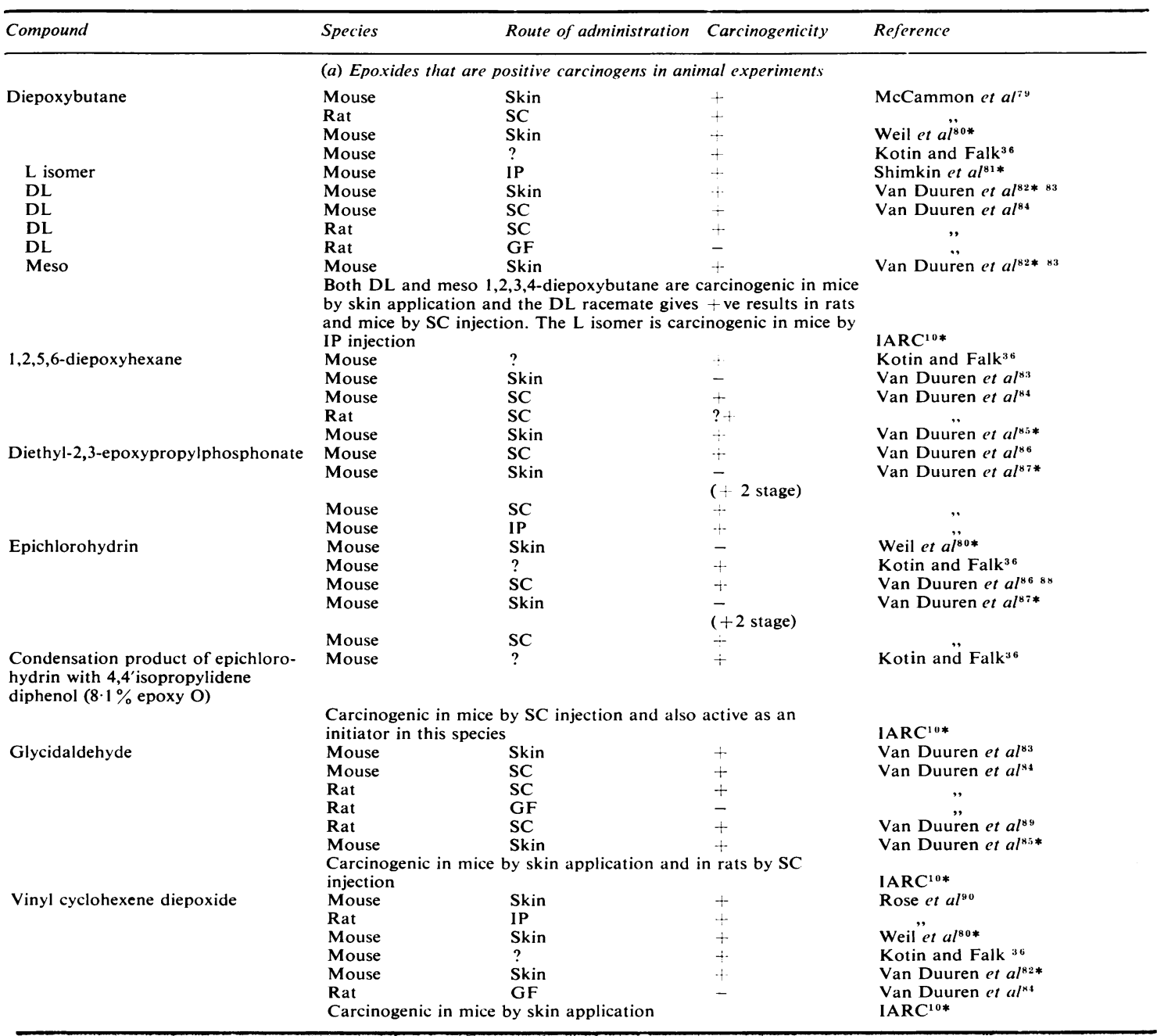


Table 5-cont

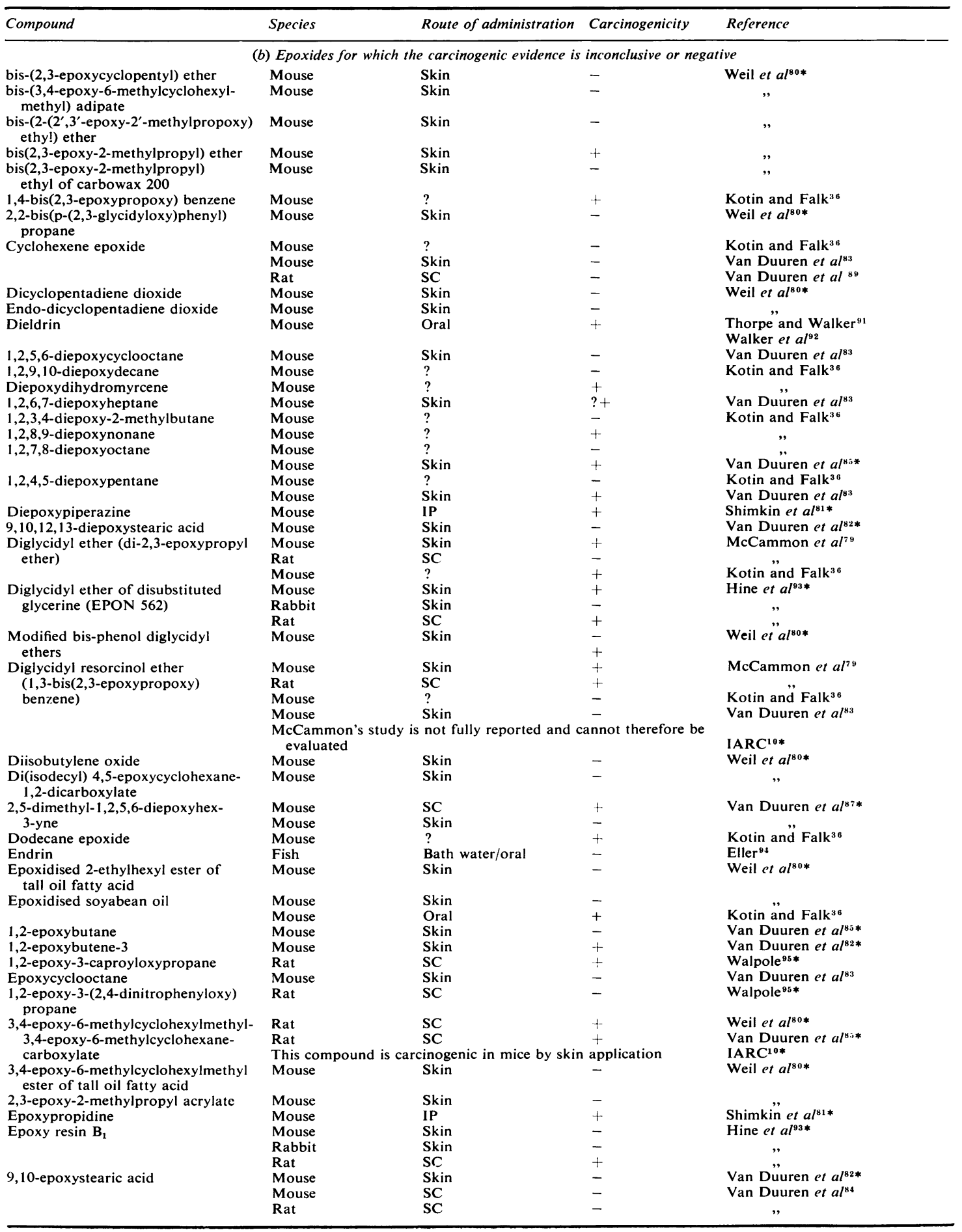


Table 5-cont

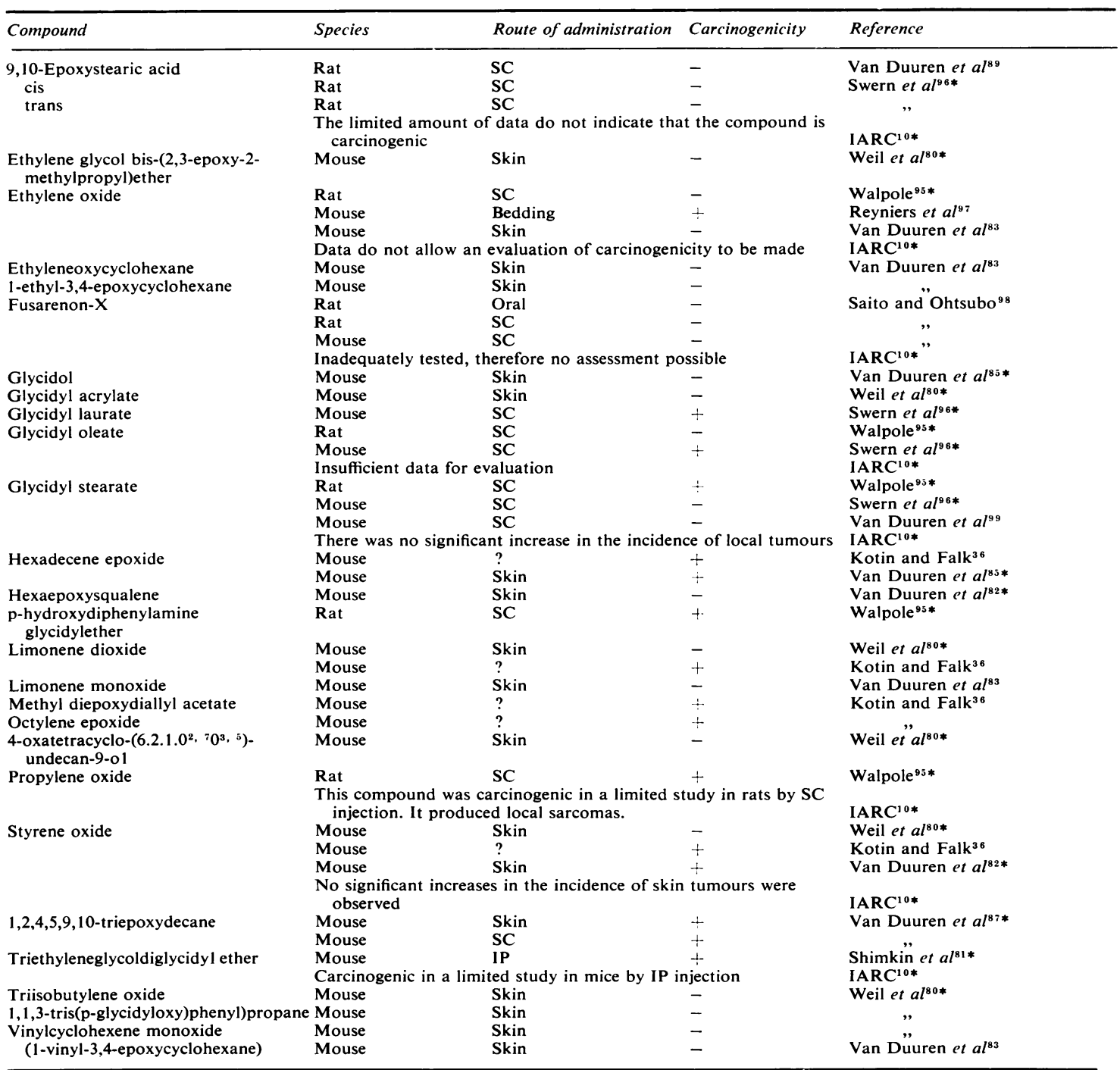

SC_-subcutaneous; IP_-intraperitoneal; GF-intragastric feeding.

* References that include structures.

period. As judged from the few authenticated cases of skin cancer of environmental origin, prolonged contact and relatively poor industrial hygiene practices would be required for the development of such tumours. Bourne et al ${ }^{108}$ emphasised that no neoplastic skin changes had been observed in man with any of the compounds used in the epoxy resin industry to that date.

The evidence for potential epoxides as human carcinogens is more convincing. Vinyl chloride and benzo(a)pyrene, both metabolised in vivo to epoxides, are now linked with human liver and scrotal cancer respectively ${ }^{109-111}$ and aflatoxin with its possible epoxide intermediate also appears to be a human hepatocarcinogen. ${ }^{112} 113$

Animal data for benzene, another potential epoxide, are not conclusive for carcinogenic activity. In man exposure to commercial benzene may result in damage to the haematopoietic system, and the development of leukaemia is suggested by many case reports. 110114

Mice given trichloroethylene by gastric intubation 
showed an unusual incidence of hepatocellular carcinomas, but this did not occur in rats. ${ }^{10}$ To date there are no published reports of any association between trichloroethylene and cancer in man. Since the announcement by the National Cancer Institute ${ }^{115}$ of trichloroethylene carcinogenicity in mice, several substitutes have been introduced in degreasing, manufacture of decaffeinated coffee, and other uses. These include 1,1,1-trichloroethane $\left(\mathrm{Cl}_{3} \mathrm{C}-\mathrm{CH}_{3}\right)$, dichloromethane $\left(\mathrm{CH}_{2} \mathrm{Cl}_{2}\right)$, tetrachloroethylene $\left(\mathrm{Cl}_{2} \mathrm{C}=\mathrm{CCl}_{2}\right)$, and hexachloroethane $\left(\mathrm{Cl}_{3} \mathrm{C}-\mathrm{CCl}_{3}\right)$. All four could be expected to cause liver damage and dichloromethane might also be a liver carcinogen. ${ }^{116}$ Tetrachloroethylene has already been shown to produce liver cancer in laboratory mice as well as other toxic effects such as fatty liver, liver enlargement, and abnormal liver function. It also causes kidney damage and neurophysiological effects. ${ }^{117}$

\section{MUTAGENICITY}

With the development of short-term testing techniques such as the Ames test, much of the more recent work on epoxides, particularly the arene oxides, has been devoted to the mechanisms of mutagenicity and carcinogenicity. The most popular methods make use of Salmonella variants of the Ames test, Neurospora crassa, Escherichia coli, Saccharomyces cerevisiae, Drosophila melanogaster, or various tissue cultures in which transformation or DNA damage can be observed.

Most epoxides, both aliphatic and aromatic, that have been adequately tested, have proved to be mutagenic in one or more systems. ${ }^{10} 118$ Mutagenic assays give some "false-positive" and some "falsenegative" results - that is, they have failed to show mutagenic activity for about $10 \%$ of established carcinogens, especially some of the weaker ones, and they have shown mutagenic activity for some chemicals that have not so far induced tumours in animal tests. ${ }^{76}$ Because of the known differences between the metabolism in in-vitro tests and the human body, short-term mutagenicity testing on its own cannot be used to predict accurately carcinogenicity in man. It may serve, however, as a useful warning.

Various types of mutation have been detected, but most of the changes to DNA concern base-pair substitutions, which give rise to genetically transmissible alterations. ${ }^{10}$ As well as indications of mutagenicity in human cell cultures exposed to epoxides such as diepoxybutane ${ }^{119}$ and epichlorohydrin, ${ }^{120} 121$ results from blood samples of workers exposed to epoxides or their precursors indicate that this might also be a problem in vivo. An increase (related to years of exposure) in chromosomal aberrations, in particular chromatid and chromo- some breaks, was found in blood samples from workers exposed to epichlorohydrin. ${ }^{122}$ Although the increase was just statistically significant, however, all the values were within the normal range. Similar results were obtained more recently by Picciano ${ }^{123}$ from a larger group of workers. Excess chromosome aberrations were also observed in lymphocytes taken from people occupationally exposed to ethylene oxide. ${ }^{124}$

Workers in the vinyl chloride/PVC industry were shown to have an increased level of chromosomal abnormalities compared with controls, which was related to job category, length of employment, experience of exposure to short-term excursion levels of vinyl chloride, and smoking habits. ${ }^{125}$ Chromosome abnormalities were also found in several workers using trichloroethylene as a degreaser. ${ }^{126}$ Chromosomes from cultured blood lymphocytes of 10 workers occupationally exposed to styrene, showed an increase (11-26\% incidence) in aberrations compared to those from normal controls $(3 \%$ or less incidence). ${ }^{127}$

\section{STRUCTURE-ACTIVITY RELATIONSHIPS}

Several attempts have been made to find a structureactivity relationship for epoxides, particularly with respect to carcinogenicity and mutagenicity. This would be valuable in predicting the toxicity of a compound.

Van Duuren ${ }^{128}$ concluded that diepoxides are more often carcinogenic than monofunctional epoxides, and some monoepoxides that he found to be carcinogenic have an additional reactive site-for example, an aldehyde group in glycidaldehyde, a double bond in 1,2-epoxybutene-3, or an unsaturated ring in styrene oxide-so that they could be considered as difunctional. Glycidol, an analogue of glycidaldehyde that lacks the aldehyde group, and the saturated analogues of the other two were inactive. In general the tumour yield was lower with monofunctional compounds than with their difunctional analogues. Consideration was also given to the distance between the epoxy functions and the flexibility of the molecules as these would seem to be relevant in any consideration of cross-linking in DNA. The findings suggested that flexibility of the reactive centres is important for carcinogenicity. Because of the substantial number of monofunctional alkylating agents, however, including some epoxides, Van Duuren concluded that bifunctionality is not a prerequisite for carcinogenic activity.

In a comparison of the mutagenicity of diepoxyoctane, a straight chain flexible diepoxide, with that of its cyclic analogue, diepoxycyclo-octane, Huang et $a^{129}$ found that in Chinese hamster lung cells 
only the former was genetically active and formed adducts with radiolabelled nucleotides. The differences in chemical and genetic activities between the two compounds were attributed to their molecular conformations and the resulting different flexibilities. This is in agreement with the carcinogenicity results of Van Duuren's group, ${ }^{85} 128$ who found that the straight chain diepoxide was positive, while the cyclic compound was negative.

Henschler and Bonse ${ }^{130}$ looked at the dependence of mutagenic effect on electrophilic activity of epoxides of chlorinated ethylenes. Electrophilicity was high in those having an asymmetric chlorine substitution and comparatively low in others bearing symmetric chlorine residues. These workers concluded that the mutagenic potential of these chlorinated compounds is related to asymmetric substitution and high chemical reactivity. Symmetric substitution results in lower chemical reactivity and nonmutagenicity. The reason for the instability of an asymmetrically substituted epoxide is the preponderance of the electron withdrawal effect of the chlorine atom(s). So far the rule is substantiated by positive carcinogenic effects in animal experiments with epoxides of vinyl chloride, vinylidene chloride, and trichloroethylene.

No completely satisfactory correlation of structure with carcinogenic potency has been developed for the polyaromatic hydrocarbons and their metabolites. The current so-called "bay region" hypothesis, however, suggests that metabolic activation in the angular ring of these hydrocarbons to produce diol epoxides, in which the epoxide oxygen is situated in the bay region, is an important pathway in the conversion of these molecules to biologically active intermediates. ${ }^{131}$

\section{TOXICITY}

The acute toxicity in terms of $\mathrm{LD}_{50}$ or $\mathbf{L C}_{50}$ in experimental animals has been calculated for several epoxides and is generally higher for the lower molecular weight compounds. ${ }^{10132}$ The mechanisms of acute toxicity and the cause of death are not clear and have been described vaguely as shock, respiratory arrest, and fatigue of the central nervous system..$^{22}$ Chronic toxicity can mean loss of body weight, gastric irritation, and slight liver damage.

The most commonly recognised effect of epoxides in man, at least from occupational exposure, is primary irritation of surface tissues, including the skin, respiratory and gastrointestinal epithelia, and the conjunctivae. Many workers complain of dermatitis. Such irritation may result from exposure to solid, liquid, or gaseous epoxides. ${ }^{80} 133$ Direct pulmonary irritation with its sequelae of pulmonary oedema and pneumonia is at least partly responsible for the toxicity of the more volatile materials. Also important in man and a not uncommon problem in industry is sensitisation. This may cause skin reactions after repeated local exposures, or asthma-like reactions of the respiratory tract after repeated inhalation of vapours.

\section{Biochemistry}

To assess the toxicity of a particular compound, one would like to know how it enters the body and is distributed, which are the target organs, whether the compound accumulates or is readily excreted, or whether it is metabolised and if so how?

Equally as important in a consideration of the risks to health from foreign compounds are questions such as: how much of the compound can be tolerated, and how often, before damage occurs? How do interactions between more than one compound alter the picture? How can the damage best be monitored and, most important, how can it be minimised or avoided? To begin to answer these questions some understanding of the biochemistry of the compound in question is necessary.

\section{Absorption and tissue distribution}

Because of their lipophilic nature, epoxides should have little difficulty in passing through cell membranes, allowing them to be widely distributed in the body. This appears to be the case in the few studies available-for example, with styrene and styrene oxide, ${ }^{134}$ ethylene oxide, ${ }^{135}{ }^{136}$ and epichlorohydrin. ${ }^{137}$ Inhaled trichloroethylene vapour is rapidly absorbed through the lungs into the blood stream and distributed throughout the body. It is also readily stored in body fat ${ }^{67}$ as are some epoxide pesticides. ${ }^{25}$

\section{Metabolism}

Most xenobiotics are metabolised to make them more readily excretable. The process may entail oxidation, reduction, or hydrolysis, usually in combination with conjugation. There are several enzymes in vivo involved in the formation or biotransformation of epoxides (fig 1) as well as the possibility of non-enzymic reactions. Many arene oxides, for example, are readily converted to corresponding phenols or conjugated to glutathione without the involvement of transferases. The three main types of enzyme are the mixed function oxidases, giving rise to epoxides in vivo, the epoxide hydratases, and glutathione-S-transferases, which metabolise epoxides to more readily excretable products. Although the whole process is often referred to as "detoxification" it is worth noting that, particularly as a result of the mixed function oxidase step, the initial metabolite may be converted to a more reactive, 


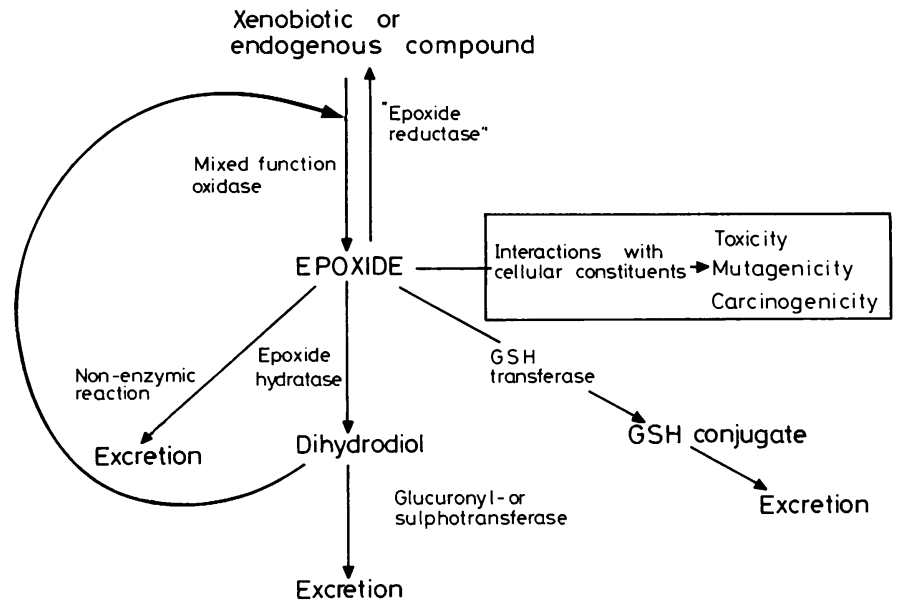

Fig 1 Epoxide metabolism. Possible pathways for formation and biotransformation of epoxides. Part of figure enclosed in box is expanded in fig 2. (For reviews see Oesch, ${ }^{138}$ Booth et al, ${ }^{139}$ Bend and Hook, ${ }^{140}$ Jerina and Bend, ${ }^{141}$ and Habig et al. ${ }^{180}$

and therefore potentially more toxic, compound.

Epoxide hydratase is also generally considered as a means of detoxification since the diol products are usually less toxic and more hydrophilic. The dihydrodiols of some polyaromatic hydrocarbons, however, may retain sufficient lipophilic character to serve again as substrates for microsomal mixed function oxidase, giving rise to the diol epoxides now believed to be the ultimate carcinogenic metabolites ${ }^{142-144}$ (see also references in section on carcinogenicity). Epoxide hydratase may therefore have a dual roleinactivating monofunctional epoxides and providing precursor molecules for dihydrodiol epoxide biosynthesis (fig 1). The liver is the main site for metabolism of xenobiotics, but these enzymes have also been found in other tissues, such as lung, kidney, small intestine, skin, and reproductive organs.

Most of the work on these enzyme systems has been carried out with respect to polyaromatic hydrocarbons, ${ }^{8}$ and of the simpler molecules most information exists for styrene oxide because this is a particularly good substrate. Thus it is not clear what part if any the enzymes play in protecting cells from the effects of smaller aliphatic epoxides such as ethylene oxide, propylene oxide, and epichlorohydrin. Possibly these are disposed of nonenzymically, since from the evidence for epoxide hydratase specificity, small highly reactive molecules do not appear to act as substrates. ${ }^{138} 145$

Metabolism is important in any consideration of the likely effects from exposure to an epoxide or its precursors. For example, the velocity of epoxidation may not be significant if subsequent reactions, such as enzymic and non-enzymic hydrolysis or conjugation with glutathione, proceed much faster than possible reactions with critical targets in the cell. To predict toxicity it would be useful to know the stability/ reactivity of the epoxide, its rate of accumulation in the cell, the proportion that reacts by each of the enzymic and non-enzymic pathways, how much epoxide reacts with cell components, and the doseresponse relation for adverse effects. Unfortunately most investigations concentrate on only one particular aspect and to complicate matters further, the relative activities of the enzymes differ between species and between tissues in any one species, and with respect to such factors as strain, sex, and developmental stages, all of which makes it extremely difficult to extrapolate from animal experiments to man.

\section{Binding to nucleic acids and proteins}

If epoxides in the cell are not disposed of, then, because of their electrophilic nature, they can combine with nucleophilic centres on nucleic acids and proteins (fig 2), and it is this binding that has been implicated in such toxic effects as mutagenesis and carcinogenesis. ${ }^{146}$ Whatever the detailed mechanism of malignant transformation, the production of DNA damage appears to be a key step. ${ }^{147}$

Several factors may affect binding ability, such as reactivity and whether the epoxide enters the body or is produced in vivo from a precursor. Some epoxides may be only transient intermediates with no time to bind to cell components because they are metabolised immediately, whereas others are so stable that they are excreted as epoxides, as occurs with some clinical drugs. ${ }^{148}$ Those with intermediate reactivity will be of interest in cellular interactions. If an epoxide is absorbed into the body it may react enzymically or non-enzymically before it has time to reach critical sites in the cell. On the other hand, such targets may be much more vulnerable to an epoxide produced in vivo by the mixed function oxidase 


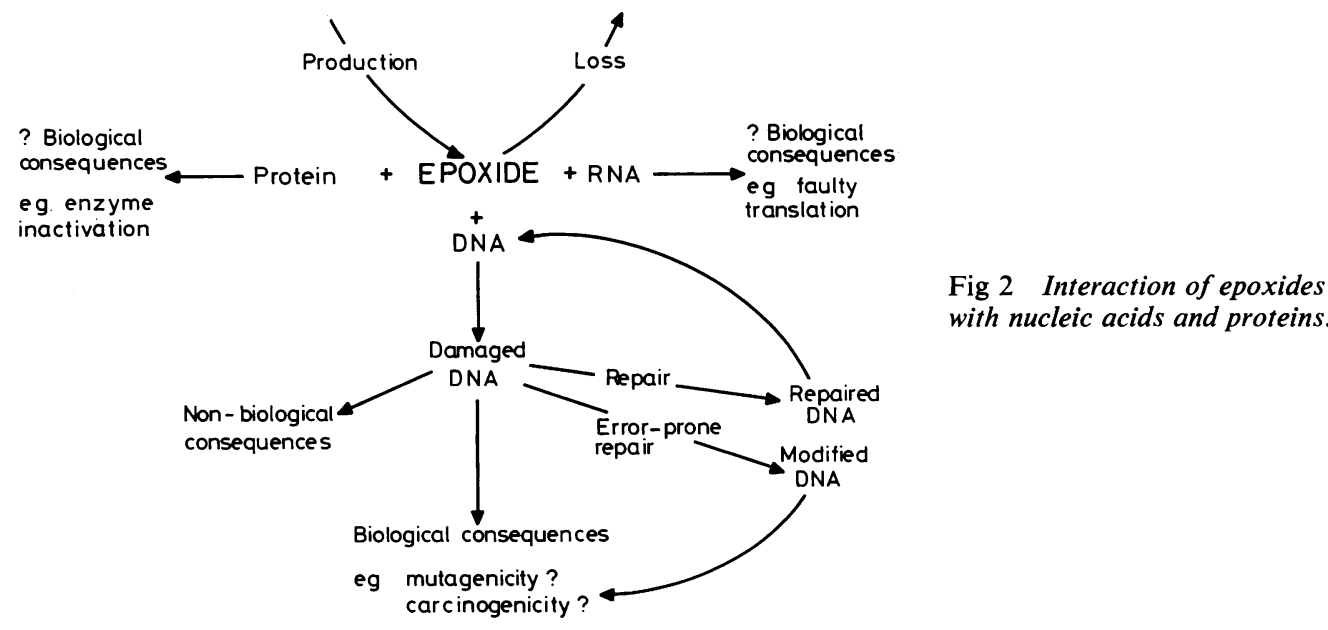

system, although in this case an epoxide hydratase may be on hand to mop up the epoxide as it is produced. The evidence so far tends to suggest that the compounds that are metabolised to epoxides in vivo are the more toxic, at least with respect to human carcinogenicity.

Several workers have tried to relate the information obtained from binding studies to the mutagenicity or carcinogenicity of a particular compound. Using a series of polyaromatic hydrocarbons, including benzo(a)pyrene, Brookes and Lawley149-151 found a positive correlation between the carcinogenic power of these substances (presumably their reactive metabolites) and the extent of their binding to DNA in mouse skin. This was subsequently confirmed by Duncan et al, ${ }^{152}$ Duncan and Brookes, ${ }^{153}$ and Buty et al. ${ }^{154}$ There was no such correlation between carcinogenicity and binding to protein or RNA.

Van Duuren ${ }^{128}$ pointed out that carcinogenic epoxides such as diepoxybutane react at the N7 position of guanine in DNA but so do apparently non-carcinogenic agents, such as ethylene oxide and propylene oxide. Therefore it is difficult to equate reaction at this site with carcinogenesis. Reaction also occurs with other bases, particularly adenine, although the extent of the reaction is generally less than with guanine. ${ }^{149}$ Also not all carcinogens react at N7, and in fact it is now believed that reaction at the N7 position of guanine has a negligible effect on the functioning of DNA, and that nucleophilic substitution at $\mathrm{O}$ atoms may lead to the formation of promutagenic bases. Alterations at other sites, however, such as N1 of adenine, may also cause distortions in the double helix which interfere with base pairing. ${ }^{147}$

Several investigators are making use of the interaction of alkylating agents with molecules in vivo in an attempt to monitor the exposure of workers to various compounds. Ehrenberg et al have pioneered a method that measures the alkylation of the amino acids cysteine and histidine in haemoglobin by compounds such as ethylene oxide. ${ }^{155} 156181$

\section{Repair mechanisms}

If epoxides bind to DNA and cause damage the cell still has one last line of defence. Since the integrity of DNA is vital to an organism, it is not surprising that some advanced enzyme repair mechanisms have evolved so that damage to DNA can be reversed, removed, or tolerated. DNA repair has been reviewed by several workers including Trosko and Chang, ${ }^{157}$ Strauss, ${ }^{158}$ and Lehmann and Bridges. ${ }^{147}$ Most of the detailed studies have been carried out on bacterial systems, but several mammalian systems have provided valuable information. Again much of the relevant work in this area has been done with arene oxides.

There are several recessively inherited human disorders in which the individuals are more prone to develop cancer. ${ }^{159}$ Several of these-namely, xeroderma pigmentosum, ataxia telangiectasia, and Fanconi's anaemia-have been shown to be associated with defects in the DNA repair mechanisms. The ability of the cell to repair lesions in DNA may greatly contribute to the resistance of the cell to transformation so that analysis of the molecular defects in these diseases should help to elucidate the molecular nature of changes responsible for cytotoxicity, mutagenicity, and carcinogenicity. 
Genetic and immunological aspects

There are several other aspects of the biochemistry of epoxides about which little is known but which might provide valuable information on how some of the toxic effects of these compounds might be avoided.

One area that is poorly understood is genetic susceptibility to the toxic effects, in particular cancer, caused by some epoxides. Differences in inducibility of aryl hydrocarbon hydroxylase, a mixed function oxidase, in various strains of mice correlate well with susceptibility of the animals to carcinogenesis after exposure to certain polyaromatic hydrocarbons. ${ }^{160}$ Studies by Kellermann et al ${ }^{161} 162$ on patients with lung cancer indicated that bronchogenic carcinoma is associated with high aryl hydrocarbon hydroxylase inducibility. In other studies, however, this correlation could not be found, although in some cases aryl hydrocarbon hydroxylase inducibility did seem to be genetically determined. ${ }^{163}$ The ability to predict how individuals would react to a particular drug or their susceptibility to cancer after exposure to environmental chemicals would be of obvious benefit.

Another area that might prove extremely useful, but in which little is known with respect to epoxides, is immunology. In a recent study using a noncarcinogenic analogue of dimethylbenzanthracene conjugated to bovine serum albumin, Moolten et al ${ }^{164}$ were able to induce in guinea pigs the formation of antibodies that bound a variety of polyaromatic hydrocarbon carcinogens and protected tissue culture cells from their toxic effects.

From the preceding biochemical discussion it may be seen that the body under normal conditions is equipped to deal with epoxides. The problem of toxicity will arise when (1) there is an inadequate defence mechanism for a particular epoxide, (2) the organism is exposed to too high a dose, or (3) interactions occur that alter the normal metabolic pathways. The first could arise if the epoxide does not act as a substrate for any of the enzymes, if it reacts with other cell components faster than with the enzymes, or if it gets into one tissue that is less able to cope than another. The third possibility is discussed in more detail below.

\section{“DRUG", INTERACTIONS}

For xenobiotics inactivated primarily by hepatic oxidative metabolism there are two important types of interaction. Firstly, one compound may inhibit the metabolism of another and secondly, prolonged administration of a drug such as phenobarbital, which induces the liver microsomal system, can stimulate the metabolism of another compound administered concomitantly. The first possibility may result in toxic concentrations of an active compound building up in various tissues. In the second case the plasma concentration of a drug may be rapidly decreased below its therapeutic level or a xenobiotic may be converted to reactive intermediates faster than these can be disposed of by the cell.

Although the question of interactions has not been widely recognised with respect to epoxides, there are one or two examples of the type of problem that can arise. The effect of synthetic steroid contraceptives on the metabolism of the epilepsy drug carbamazepine was studied in rats. The latter is metabolised via a stable epoxide, which was shown to be a poor substrate for epoxide hydratase. 165166 The steroids increased the formation of carbamazepine-10,11epoxide by inducing the mixed function oxidase system. This induction appeared to be speciesdependent, occurring in mice and rats but not in guinea pigs. Also within a species various steroids behave differently. ${ }^{167}$ 10,11-Epoxides of carbamazepine, cyproheptadine, and cyclobenzaprine were found to inhibit the hydration of styrene oxide and the latter two the hydration of benzo(a)pyrene-4,5oxide in liver microsomes of male rats. ${ }^{65}$ Pachecka et al ${ }^{168}$ using a different strain of rat, also found that cyproheptadine inhibited epoxide hydratase activity with respect to styrene oxide, but reported that cyclobenzaprine epoxide showed a slight stimulatory effect. In an in-vivo study in rats Salmona et al ${ }^{169}$ found that carbamazepine increased the hydration, but not the formation, of styrene oxide.

Andersen et al ${ }^{170}$ investigated the increased toxicity of 1,1-dichloroethylene in the presence of various epoxides and concluded that the latter were interfering with the metabolism of a toxic product of 1,1-dichloroethylene microsomal oxidation.

Thomson et al ${ }^{171}$ considered the problem of high risk of malignancy in workers exposed simultaneously to asbestos and to benzo(a)pyrene inhaled in cigarette smoke. Evidence suggested that trace metals (contaminants associated with asbestos) may play a part in benzo(a)pyrene binding to macromolecules and therefore in its carcinogenicity. Most of the metals tested reduced the extent of binding in microsomal incubations containing exogenous DNA. Iron, however, had the effect of increasing the binding to components other than DNA in vitro.

Intolerance to alcohol in people exposed to trichloroethylene was investigated by Bardodēj et al. ${ }^{172} 173$ In adult male volunteers exposure to a combination of trichloroethylene and alcohol impared mental capacity more than exposure to either alone, ${ }^{174}$ and there also appeared to be an increase in toxicity to the liver. ${ }^{175} 176$ Radike et al ${ }^{177}$ have shown synergistic effects between ingested alcohol and inhaled vinyl chloride in the induction 
of angiosarcomas in rats. This is presumably due to ethanol stimulating alcohol dehydrogenase and mixed function oxidase enzymes of the liver, both of which metabolise vinyl chloride.

\section{Discussion}

Epoxides are to be found in air, soil, water, food, micro-organisms, and certain biochemical pathways, and in vast quantities in industry. In addition the number of unsaturated organic compounds, from which epoxide formation in vivo has been shown, is continually increasing. In fact it has been suggested that for polyaromatic hydrocarbons this is an obligatory step in metabolism. Thus the question is not whether exposure occurs, but which compounds are a threat to health and what levels can be tolerated. The fact that most forms of life, including ourselves, are equipped with enzyme systems to dispose of epoxides suggests that cells are designed to cope with a certain level of these compounds, even if only from internal metabolic pathways. Therefore it is important to identify conditions under which an individual's exposure to epoxides or unsaturated precursors is appreciably increased-for example, in certain industrial settings, after accidents where large quantities are released into the atmosphere, by smoking or taking drugs, or in contaminated food. Although the irritating effects of most of these compounds ought to prevent excessive exposure in the work place, it is not clear from the toxicity data what are the long-term effects of regular exposure to concentrations less than those which cause irritation.

In 1978 halogenated alkyl epoxides were selected as one category of chemicals to which the US Environmental Protection Agency should give priority for epidemiological studies and testing of health and environmental effects under the 1976 Toxic Substances Control Act. Selection is based on such factors as production volume, potential human exposure or widespread environmental distribution, and lack of adequate toxicology studies. ${ }^{178}$

Sensitive detection methods are required to identify individuals who have been exposed, and some knowledge of dose-response relations is necessary to predict the likely toxic effects of such exposure. The general clinical effects have been quite well described for several aliphatic epoxides, although there is little on the mechanisms causing such effects as skin irritation, depression of the central nervous system, or damage to the haematopoietic system. There are many epoxides that have not been tested for carcinogenicity, but even for those that have been tested, the data are often inadequate to state conclusively whether they are positive or negative in this respect. There is not yet enough epidemiological data to indicate convincingly whether epoxides in the environment can act as human carcinogens, although there is positive evidence for several of the potential epoxides. Most epoxides that have been tested for mutagenicity are positive in one or more systems, even those that are consistently negative in animal carcinogenicity tests. Several of these compounds have produced detectable chromosome aberrations in workers' blood. Thus it seems that most epoxides can interact with the genetic material in the cell, although the significance of this in vivo is poorly understood.

With respect to structure-activity relations only the most general and preliminary comments can be made. It may be possible to rank the compounds on the basis-the more electrophilic, the more reactive and thus the more potentially toxic. Of the aliphatic epoxides tested, features such as difunctionality and flexibility occurred more frequently among those for which there was some evidence of carcinogenicity.

The biochemical information for epoxides is also incomplete and mostly concentrated in one or two areas, such as enzymology, and on one or two particular compounds-for instance, styrene oxide or benzo(a)pyrene oxides. Tissue distribution has only been studied for a few epoxides so that the question of target organs is not well understood, although some of these compounds do not appear to be highly selective. Much work has been done on the enzyme systems involved in epoxide formation and biotransformation, including their activities in various tissues. Since most studies of this type have been done with polyaromatic hydrocarbons, however, it is not clear what part, if any, the enzymes play in the disposal of the smaller aliphatic epoxides. Another interesting question with regard to the enzymes is that of complementary action. Since there are two major pathways for removing epoxides, involving either epoxide hydratase or glutathione-S transferase, are these enzymes independent or do they complement each other with respect to levels in a particular tissue, levels at different stages of development, or the substrates that they metabolise? There is some evidence for all three of these possibilities.

Several types of binding to cell components have been shown for epoxides in vitro, but it is not clear which interactions in vivo cause detrimental biological effects. Nor is enough known about repair systems to predict how much damage can be tolerated or even which types of damage can be repaired routinely.

Interactions between different epoxides or between an epoxide and another chemical should not be overlooked. A great deal more information is required, however, to assess the resultant toxicity under these conditions. Is there an increased risk to an individual 
who is occupationally exposed to styrene or styrene oxide and who is simultaneously undergoing treatment with one of the drugs listed in table 4 ? Is a smoker more susceptible than a non-smoker to the toxic effects of an epoxide in the atmosphere? Results from workers in the vinyl chloride industry suggest that this may be the case. ${ }^{125}$ Even if interactions do not enhance the acute toxicity, they may potentiate mutagenic or carcinogenic effects of one of the compounds, a problem that might not become apparent for many years. It is also possible to conceive of interactions having a beneficial effect. For example, if a compound that inhibited the activity of the mixed function oxidase system were present at the same time as a polyaromatic hydrocarbon, the latter may not be metabolised to its toxic intermediate.

\section{Conclusions}

Both occupational and non-occupational exposure to epoxides occurs, but most of the data are for compounds metabolised to epoxides rather than for epoxides themselves. Much of the information on toxicity of epoxides is qualitative, with little on mechanism of toxicity or dose-response relations.

Most epoxides are toxic to man to some extent (even if the main industrial problem is only irritation of the surface tissues) and ironically some of the more toxic compounds may be those which are metabolised to epoxides in vivo. At present there is no convincing evidence that exposure to epoxides per se causes cancer in man, but there is evidence for several unsaturated compounds such as vinyl chloride, benzo(a)pyrene, and aflatoxin.

Not enough is known about the possible longterm effects to state with certainty a safe level of exposure to epoxides or their precursors, and more epidemiological research and sensitive methods for measuring human exposure are required.

\section{References}

${ }^{1}$ Tanaka Y, Okada A, Tamizuka I. Synthesis and characteristics of epoxides. In: May CA, Tanaka Y, eds. Epoxy resins-chemistry and technology. New York: Dekker Inc, 1973:9-133.

${ }^{2}$ Bratzel RP, Goodridge TH, Huntress WT. A survey of alkylating agents tested against cancer or described in the literature as prepared for such testing. Survey of epoxides and episulphides. Cancer Chemotherapy Reports 1963;26:445-506.

${ }^{3}$ Cross AD. The chemistry of naturally occurring 1,2 epoxides. Quarterly Reviews 1960;14:317-35.

${ }^{4}$ Daly JW, Jerina DM, Witkop B. Arene oxides and the NIH shift: the metabolism, toxicity and carcinogenicity of aromatic compounds. Experientia 1972;28:1129-49.
5 Jerina DM, Daly JW. Arene oxides: a new aspect of drug metabolism. Science 1974;185:573-82.

- Sims P, Grover PL. Epoxides in polycyclic aromatic hydrocarbon metabolism and carcinogenesis. Adv Cancer Res 1974;20:165-274.

' Freudenthal RI, Jones PW, eds. Carcinogenesis-A comprehensive survey. Vols 1-3. New York: Raven Press, 1976-8.

${ }^{8}$ DePierre JW, Ernster L. The metabolism of polycyclic hydrocarbons and its relationship to cancer. Biochim Biophys Acta 1978;473:149-86.

${ }^{9}$ Kadis B. Steroid epoxides in biologic systems: a review. J Steroid Biochem 1978;9:75-81.

10 IARC Epoxides. Cadmium, nickel, some epoxides, miscellaneous industrial chemicals and general considerations on volatile anaesthetics. Vol 11. Lyon: International Agency for Research on Cancer Monographs on the Evaluation of Carcinogenic Risk of Chemicals to Man, 1976:115-214.

${ }^{11}$ Storck WJ. C and EN's top 50 chemical products and producers-production rises for most major chemicals. Chemistry and Engineering News 1978 May 1:32-7.

12 Pearce EM, Liepins R. Flame retardants. Environ Health Perspect 1975;11:59-69.

${ }^{13}$ Starks FW. Stabilisation of chlorinated hydrocarbons. United States Patent No 2818 446. 1957.

14 Grindley PR. Stabilizers for polyvinyl chloride. Chemical Processing 1969;15:8-11.

${ }^{15}$ Henschler D, Eder E, Neudecker T, Metzler M. Carcinogenicity of trichloroethylene: fact or artifact. Arch Toxicol 1977;37:233-6.

${ }^{16}$ Port WS. Epoxy compounds as polymer stabilizers and plasticizers. In: May CA, Tanaka Y, eds. Epoxy resinschemistry and technology. New York: Dekker, 1973: 633-52.

${ }^{17}$ Szczeszek M. Stabilisation of chlorinated hydrocarbons. Chemik 1976;29:298-301. (Polish.)

${ }^{18}$ Whitbourne J, West K. Ethylene oxide application. Developments in Industrial Microbiology 1975;16:57-66.

${ }^{19}$ Samuels TM. Personnel exposure to ethylene oxide in a central service assembly and sterilization area. Hosp Top $1978 ; 56: 27-33$.

${ }^{20}$ Health and Safety Executive. Threshold limit values for 1976. Guidance Note EH 15/76. London: HSE:1976.

${ }^{21}$ Segal A, Loewengart G, Sudberg S. A new personal monitoring device for the detection of $\beta$-propriolactone and other alkylating agents. Arch Environ Health 1978; 33:33-5.

${ }^{22}$ Borgstedt $\mathrm{HH}$, Hine $\mathrm{CH}$. Toxicity, hazards and safe handling. In: May CA, Tanaka Y, eds. Epoxy resinschemistry and technology. New York: Dekker Inc, 1973:697-736.

${ }^{23}$ Black HS, Lo W-B. Formation of a carcinogen in human skin irradiated with ultraviolet light. Nature 1971;234: 306-7.

${ }^{24}$ Lo, WB, Black HS. Formation of cholesterol-derived photo-products in human skin. J Invest Dermatol 1972; $58: 278-83$.

${ }^{25}$ IARC. Some organochlorine pesticides. Vol 5. Lyon: International Agency for Research on Cancer Monographs on the Evaluation of Carcinogenic Risk of Chemicals to Man, 1974: aldrin 25-38, dieldrin 125-56, endrin 157-71, heptachlor 173-91.

${ }^{28}$ Kulkarni RK, Bartak D, Ousterhout DK, Leonard F. Determination of residual ethylene oxide in catheters by gas-liquid chromatography. J Biomed Mater Res 1968; 2:165-71.

${ }^{27}$ Fishbein L. Degradation and residues of alkylating agents. Ann NY Acad Sci 1969;163:869-94.

${ }^{28}$ Gunther DA. Determination of adsorbed ethylene and 
propylene oxides by distillation and titration. Anal Chem 1965;37:1172-3.

${ }^{29}$ Andersen SR. Ethylene oxide toxicity. A study of tissue reactions to retained ethylene oxide. JLab Clin Med 1971; 77:346-56.

30 Taylor JS. Dermatologic hazards from ethylene oxide. Cutis 1977;19:189-92.

${ }^{31}$ Wesley F, Rourke B, Darbishire $O$. The formation of persistent toxic chlorohydrins in foods by fumigation with ethylene oxide and propylene oxide. Journal of Food Science 1965;30:1037-42.

${ }^{32}$ Muramatsu M, Obi Y, Shimada Y, Takahashi K, Nishida K. Ethylene oxide in cigaret smoke. Nippon Senbai Kosha Chuo Kenkyusho Kenkyu Hokoku (Japan) 1968; 110:217-22.

${ }^{33}$ Gordon WL. The occurrence of Fusarium species in Canada. II Prevalence and taxonomy of Fusarium species in cereal seed. Canadian Journal of Botany 1952;30: 209-51.

${ }^{34}$ Lim G. Fusarium populations in rice field soils. Phytopathology 1967;57:1152-3.

${ }^{35}$ Hirashima T, Oguma T, Hosogai Y, Fuji S. Gaseous antimicrobial agents. III Determination of propylene oxide residue in food wrappings and containers. Shokuhin Eiseigaku Zasshi (Japan) 1970;11:161-3.

${ }^{36}$ Kotin P, Falk HL. Organic peroxides, hydrogen peroxide, epoxides and neoplasia. Radiat Res Suppl 1963;3:193211.

37 Van Duuren BL. Epoxides, hydroperoxides and peroxides in air pollution. International Journal of Environmental Analytical Chemistry 1972;1:233-41.

${ }^{38}$ Rosenkranz HS, Wlodkowski TJ. Mutagenicity of ethylene chlorohydrin. A degradation product present in foodstuffs exposed to ethylene oxide. J Agric Food Chem 1974;22:407-9.

${ }^{39}$ Rosenkranz HS, Wlodkowski TJ, Bodine SR. Chloropropanol a mutagenic residue resulting from propylene oxide sterilization. Mutat Res 1975;30:303-4.

${ }^{40}$ Deatherage FE, Mattill HA. Antioxidants and the autoxidation of fats. Autoxidation of oleic acid, methyl oleate, oleyl alcohol and cis-9-octadecene. Industrial and Engineering Chemistry 1939;31:1425-31.

${ }^{11}$ Swift CE, Dollear FG. The oxidation of methyl oleate. II A reaction between methyl hydroperoxido oleate and oleic acid. J Am Oil Chem Soc 1948;25:52-3.

${ }^{12}$ Bamburg JR, Strong FM. 12,13-Epoxytrichothecenes. In: Kadis S, Ciegler A, Ajl SJ. Microbiol toxins-a comprehensive treatise. VII Algal and fungal toxins. New York, London: Academic Press, 1971:207-92.

${ }^{43}$ Rodricks JV, Hesseltine CW, Mehlman MA, eds. Mycotoxins in human and animal health. Illinois: Pathotox Publishers Inc, 1977.

${ }^{44}$ Hendry JA, Homer RF, Rose FL, Walpole AL. Cytotoxic agents: II Bisepoxides and related compounds. $\mathrm{Br} J$ Pharmacol $1951 ; 6: 235-55$

${ }^{15}$ Bardodéj Z. Metabolic studies and the evaluation of genetic risk from the viewpoint of industrial toxicology. Mutat Res 1976;41:7-14.

${ }^{46}$ Lorimer WV, Lilis R, Nicholson WJ, et al. Clinical studies of styrene workers: initial findings. Environ Health Perspect 1976;17:171-81.

${ }^{17}$ Härkönen H, Lindström K, Seppäläinen ZM, Asp S, Hemberg S. Exposure-response relationship between styrene exposure and central nervous functions. Scand $J$ Work, Environ Health 1978;4:53-9.

18 Barsotti M, Parmeggiani L, Sassi C. Osservazioni di patologia professionale in una fabbrica di resine polistiroliche. Med Lav 1952;43:418-24.

${ }^{19}$ Tatsuno T, Kuroki T. Hygienic chemical aspects of plastics. II Quantitative determination of volatile matters in commercial polystyrene wares. Eisei Shikenjo Hokoku 1971;89:122-4.

50 Van Grimbergen M, Reybrouck G, Van de Voorde H. Development of impurities in the air by burning thermoplastics. Zentralbl Bakteriol (Orig Reihe B). 1971; 155:123-30.

${ }^{51}$ Axelson $\mathrm{O}$, Andersson $\mathrm{K}$, Hogstedt C, Holmberg B, Molina G, de Verdier A. A cohort study on trichloroethylene exposure and cancer mortality. JOM 1978; 20:194-6.

52 Lloyd JW, Moore RM, Breslin P. Background information on trichloroethylene. JOM 1975;17:603-5.

${ }^{53}$ Corbett TH. Retention of anesthetic agents following occupational exposure. Anesth Analg 1973;52:614-8.

${ }^{54}$ Corbett TH. Cancer and congenital anomalies associated with anesthetics. Ann NY Acad Sci 1976;271:58-66.

${ }^{55}$ Karstadt M. PVC: health implications and production trends. Environ Health Perspect 1976;17:107-15.

${ }^{56}$ Cohan GF. Industrial preparation of poly(vinyl chloride). Environ Health Perspect 1975;11:53-7.

${ }^{57}$ Bridbord K, Brubaker PE, Gay B, French JG. Exposure to halogenated hydrocarbons in the indoor environment. Environ Health Perspect 1975; 11 :215-20.

58 Bridbord K, Finklea JF, Wagoner JK, Moran JB, Caplan P. Human exposure to polynuclear aromatic hydrocarbons. In: Freudenthal RI, Jones PW, eds. Carcinogenesis: a comprehensive survey. Vol 1. Polynuclear aromatic hydrocarbons: chemistry, metabolism and carcinogenesis. New York: Raven Press, 1976:319-24.

${ }^{59}$ Detroy RW, Lillehoj EB, Ciegler A. Aflatoxin and related compounds. In: Ciegler A, Kadis, S, Ajl SJ, eds. Microbial toxins-a comprehensive treatise. VI Fungal toxins. New York and London: Academic Press, 1971:3-178.

${ }^{\text {Bo }}$ Decker GC, Bruce WN, Bigger JH. The accumulation or dissipation of residues resulting from the use of aldrin in soils. J Econ Entomol 1965;58:266-71.

${ }^{61}$ IARC Certain polycyclic aromatic hydrocarbons and heterocyclic compounds. Vol 3. Lyon: International Agency for Research on Cancer Monographs on the Evaluation of Carcinogenic Risk of Chemicals to Man, 1973: benzo(a)pyrene 91-136.

${ }^{62}$ Surgeon General's Report. Smoking and health. Washington DC: Government Printing Office, 1964. (Public Health Service Publication No 1103.)

${ }^{63}$ Wynder EL, Hoffmann D, eds. Tobacco and tobacco smoke. Studies in experimental carcinogenesis. London, New York: Academic Press, 1967.

${ }^{64}$ Akin FJ, Snook ME, Severson RE, Chamberlain WJ, Walters DB. Identification of polynuclear aromatic hydrocarbons in cigarette smoke and their importance as tumorigens. J Natl Cancer Inst 1976;57:191-5.

${ }^{65}$ Oesch F. Metabolic transformation of clinically used drugs to epoxides: new perspectives in drug-drug interactions. Biochem Pharmacol 1976;25:1935-7.

${ }^{66}$ Withey JR. Quantitative analysis of styrene monomer in polystyrene and foods, including some preliminary studies of the uptake and pharmacodynamics of the monomer in rats. Environ Health Perspect 1976;17: 125-33.

${ }^{67}$ Seltzer RJ. Reactions grow to trichloroethylene alert. Chemical and Engineering News 1975 May 19:41-3.

${ }^{68}$ Environmental Protection Agency. Scientific and technical assessment report on vinyl chloride and polyvinyl chloride. Washington DC: Office of Research and Development, 1975.

${ }^{69}$ Environmental Protection Agency. Preliminary assessment of suspected carinogens in drinking water. An interim report to Congress, Office of Toxic Substances. Washington, DC: EPA, 1975.

${ }^{70}$ Van Esch GJ, Van Logten MJ. Vinyl chloride: a report of 
a European assessment. Food Cosmet Toxicol 1975,13: 121-39.

${ }^{71}$ Williams DT, Miles WF. Gas-liquid chromatographic determination of vinyl chloride in alcoholic beverages, vegetable oils and vinegars. $J$ Assoc Off Anal Chem 1975;58:272-5.

${ }^{72}$ Hoffmann D, Patrianakos C, Brunnemann KD, Gori GB. Chromatographic determination of vinyl chloride in tobacco smoke. Anal Chem 1976;48:47-50.

${ }^{73}$ Garner RC, Wright CM. Induction of mutations in DNArepair deficient bacteria by a liver microsomal metabolite of aflatoxin $\mathrm{B}_{1}$. Br J Cancer 1973;28:544-51.

${ }^{74}$ Swenson DH, Miller EC, Miller JA. Aflatoxin B-2-3oxide: evidence for its formation in rat liver in vivo and by human liver microsomes in vitro. Biochem Biophys Res Commun 1974;60:1036-43.

${ }^{75}$ Swenson DH, Lin J-K, Miller EC, Miller JA. Aflatoxin $B_{1}$-2,3-oxide as a probable intermediate in the covalent binding of aflatoxins $B_{1}$ and $B_{2}$ to rat liver DNA and ribosomal RNA in vivo. Cancer Res 1977;37:172-81.

${ }^{76}$ Miller EC. Some current perspectives on chemical carcinogenesis in humans and experimental animals: presidential address. Cancer Res 1978;38:1479-96.

${ }^{77}$ Campbell TC, Hayes JR. The role of aflatoxin metabolism in its toxic lesion. Toxicol Appl Pharmacol 1976;35: 199-222.

${ }^{78}$ Boyland $\mathrm{E}$. The biological significance of metabolism of polycyclic compounds. Biochem Soc Symp 1950;5:40-54.

${ }^{79}$ McCammon CJ, Kotin P, Falk HL. The carcinogenic potency of certain diepoxides. Proceedings of the American Association for Cancer Research 1957;2: 229-30.

${ }^{80}$ Weil CS, Condra N, Haun C, Striegel JA. Experimental carcinogenicity and acute toxicity of representative epoxides. Am Ind Hyg Assoc J 1963;24:305-25.

${ }^{81}$ Shimkin MB, Weisburger, JH Weisburger EK, Gubare ff $\mathrm{N}$, Suntzeff V. Bioassay of 29 alkylating chemicals by the pulmonary tumor response in strain A mice. $J$ Natl Cancer Inst 1966;36:915-35.

${ }^{82}$ Van Duuren BL, Nelson N, Orris L, Palmes ED, Schmitt FL. Carcinogenicity of epoxides, lactones and peroxy compounds. J Natl Cancer Inst 1963;31:41-55.

${ }^{83}$ Van Duuren BL, Orris L, Nelson N. Carcinogenicity of epoxides, lactones and peroxy compounds. Part II. J Natl Cancer Inst 1965;35:707-17.

${ }^{84}$ Van Duuren BL, Langseth L, Orris L, Teebor G, Nelson N, Kuschner M. Carcinogenicity of epoxides, lactones and peroxy compounds. IV Tumour response in epithelial and connective tissue in mice and rats. $J$ Natl Cancer Inst 1966;37:825-34.

${ }^{85}$ Van Duuren BL, Langseth L, Goldschmidt BM, Orris L. Carcinogenicity of epoxides, lactones and peroxy compounds. VI Structure and carcinogenic activity. J Natl Cancer Inst 1967;39:1217-26.

${ }^{86}$ Van Duuren BL, Katz C, Goldschmidt BM. Direct acting alkylating carcinogens. Chloroether and related compounds. Toxicol Appl Pharmacol 1972;22:279-80.

${ }^{87}$ Van Duuren BL, Goldschmidt BM, Katz C, Seidman I, Paul JS. Carcinogenic activity of alkylating agents. $J$ Natl Cancer Inst 1974;53:695-700.

${ }^{88}$ Van Duuren BL, Katz C, Goldschmidt BM, Frenkel K, Sivak A. Carcinogenicity of haloethers. II Structureactivity relationships of analogs of bis(chloromethyl) ether. J Natl Cancer Inst 1972;48:1431-9.

${ }^{89}$ Van Duuren BL, Langseth L, Orris L, Baden M, Kuschner $M$. Carcinogenicity of epoxides, lactones and peroxy compounds. V Subcutaneous injection in rats. $J$ Natl Cancer Inst 1967;39:1213-6.

${ }^{90}$ Rose FL, Hendry JA, Walpole AL. New cytotoxic agents with tumour-inhibitory activity. Nature 1950;165:993-6.
${ }^{91}$ Thorpe E, Walker AIT. The toxicology of dieldrin (HEOD). II Comparative long-term oral toxicity studies in mice with dieldrin, DDT, phenobarbitone, $\beta$-BHC and $\gamma$-BHC. Food Cosmet Toxicol 1973;11:433-42.

${ }_{92}$ Walker AIT, Thorpe E, Stevenson DE. The toxicology of dieldrin (HEOD). I Long-term oral toxicity studies in mice. Food Cosmet Toxicol 1973;11:415-32.

${ }^{93}$ Hine $\mathrm{CH}$, Guzman RJ, Coursey MM, Wellington JS, Anderson $\mathrm{HH}$. An investigation of the oncogenic activity of two representative epoxy resins. Cancer Res 1958;18:20-6.

${ }^{94}$ Eller LL. Histopathologic lesions in cutthroat trout (Salmo clarki) exposed chronically to the insecticide endrin. Am J Pathol 1971;64:321-30.

${ }^{95}$ Walpole AL. Carcinogenic action of alkylating agents. Ann NY Acad Sci 1958;68:750-61.

${ }^{96}$ Swern D, Wieder $\mathrm{R}$, McDonough $\mathrm{M}$, Meranze DR, Shimkin MB. Investigation of fatty acids and derivatives for carcinogenic activity. Cancer Res 1970;30:1037-46.

97 Reyniers JA, Sacksteder MR, Ashburn LL. Multiple tumors in female germfree inbred albino mice exposed to bedding treated with ethylene oxide. $J$ Natl Cancer Inst 1964;32:1045-57.

${ }^{98}$ Saito M, Ohtsubo K. Trichothecene toxins of Fusarium species. In: Purchase IFH, ed. Mycotoxins. Amsterdam: Elsevier, 1974:263-81.

99 Van Duuren BL, Katz C, Shimkin MB, Swern D, Wieder R. Replication of low-level carcinogenic activity bioassays. Cancer Res 1972;32:880-1.

${ }^{100}$ Sims P, Grover PL, Swaisland A, Pal K, Hewer A. Metabolic activation of benzo[a]pyrene proceeds by a diol-epoxide. Nature 1974;252:326-8.

${ }^{101}$ Huberman E, Sachs L, Yang SK, Gelboin HV. Identification of mutagenic metabolites of benzo[a]pyrene in mammalian cells. Proc Natl Acad Sci USA, 1976;73: 607-11.

102 Jerina DM, Yagi H, Hernandez O, et al. Synthesis and biological activity of potential benzo[a]pyrene metabolites. In: Freudenthal RI, Jones PW, eds. Carcinogenesis-a comprehensive survey. Vol 1 Polynuclear aromatic hydrocarbons: chemistry, metabolism and carcinogenesis. New York: Raven Press, 1976:91-113.

${ }^{103}$ Weinstein IB, Jeffrey AM, Jennette KW, et al. Benzo[a] pyrene diol epoxides as intermediates in nucleic acid binding in vitro and in vivo. Science 1976;193:592-5.

${ }^{104}$ Kapitulnik J, Levin W, Conney AH, Yagi H, Jerina DM. Benzo(a)pyrene 7,8-dihydrodiol is more carcinogenic than benzo(a)pyrene in newborn mice. Nature 1977 ; 266:378-80.

${ }^{105}$ Levin W, Wood AW, Chang RL, et al. Marked differences in the tumour-initiating activity of optically pure $(+)$ - and (-)-trans-7,8 dihydroxy-7,8-dihydrobenzo [a]pyrene on mouse skin. Cancer Res 1977;37:2721-5.

${ }^{106}$ Cavalieri E, Roth R, Rogan E, Grandjean C, Althoff J. Mechanisms of tumour initiation by polycyclic aromatic hydrocarbons. In: Jones PW, Freudenthal RI, eds. Carcinogenesis-a comprehensive survey. Vol 3 Polynuclear aromatic hydrocarbons. Second international symposium on analysis, chemistry and biology. New York: Raven Press, 1978:273-84.

107 Hogstedt C, Rohlen D, Berndtsson BS, Axelson O, Ehrenberg L. A cohort study of mortality and cancer incidence in ethylene oxide production workers. $\mathrm{Br} J$ Ind Med 1979;36:276-80.

108 Bourne LB, Milner FJM, Alberman KB. Health problems of epoxy resins and amine-curing agents. $B r J$ Ind Med 1959;16:81-97.

${ }^{109}$ Creech JL, Johnson MN. Angiosarcoma of the liver in the manufacture of polyvinyl chloride. JOM 1974;16: 150-1. 
110 IARC. Some anti-thyroid and related substances, nitrofurans and industrial chemicals. Vol 7. Lyon: International Agency for Research on Cancer Monographs on the Evaluation of Carcinogenic Risk of Chemicals to Man, 1974: benzene 203-21, vinyl chloride 291-318.

${ }^{111}$ Infante PF, Wagoner JK, Waxweiler RJ. Carcinogenic, mutagenic and teratogenic risks associated with vinyl chloride. Mutat Res 1976;41:131-42.

112 Campbell TC, Stoloff L. Implications of mycotoxins for human health. J Agric Food Chem 1974;22:1006-15.

113 Wogan GN. Dietary factors and special epidemiological situations of liver cancer in Thailand and Africa. Cancer Res 1975;35:3499-502.

114 Vigliani EC, Forni A. Benzene and leukaemia. Environ Res 1976;11:122-7.

115 National Cancer Institute. Carcinogenesis bioassay of trichloroethylene. Carcinogenesis Technical Report Series No 2, CAS No 79-01-6 NCI-CG-TR-2. Washington, DC: United States Department of Health, Education and Welfare, 1976.

${ }^{116}$ Van Duuren BL. Chemical structure, reactivity, and carcinogenicity of halohydrocarbons. Environ Health Persp 1977;21:17-23

117 National Institute for Occupational Safety and Health. Tetrachloroethylene (perhlocroethylene). Current Intelligence Bulletin 20. Washington, DC: United States Department of Health, Education and Welfare, 1978. (Publication No 78-112, January 20.)

${ }^{118}$ McCann J, Choi E, Yamasaki E, Ames BN. Detection of carcinogens as mutagens in the Salmonella/microsome test: assay of 300 chemicals. Proc Natl Acad Sci USA 1975;72:5135-9.

${ }^{119}$ Auerbach AD, Wolman SR. Susceptibility of Fanconi's anaemia fibroblasts to chromosome damage by carcinogens. Nature 1976;261:494-6.

${ }^{120}$ KuČerová M, Polívková Z, Śrám R, Matoušek V Mutagenic effect of epichlorohydrin. I Testing on human lymphocytes in vitro in comparison with TEPA. Mutat Res 1976;34:271-8.

${ }^{121}$ Srám R, Cerna $M$, Kučerová $M$. The genetic risk of epichlorohydrin as related to the occupational exposure. Biologisches Zentralblatt 1976;95:451-62.

${ }^{122}$ Kučerová M, Zhurkov VS, Polívková Z, Ivanova JE. Mutagenic effect of epichlorohydrin. II Analysis of chromosomal aberrations in lymphocytes of persons occupationally exposed to epichlorohydrin. Mutat Res 1977;48:355-60.

${ }^{123}$ Picciano D. Cytogenetic investigation of occupational exposure to epichlorohydrin. Mutat Res 1979;66:169-73.

${ }^{124}$ Ehrenberg L, Hällström T, communicated by Kalling LO. Haematologic studies on persons occupationally exposed to ethylene oxide. In: Radiosterilisation of medical products. SM92/26. Vienna: International Atomic Energy Agency, 1967:327-34.

${ }^{125}$ Purchase IFH, Richardson CR, Anderson D, Paddle GM, Adams WGF. Chromosomal analyses in vinyl chlorideexposed workers. Mutat Res $1978 ; 57: 325-34$.

${ }^{126}$ Konietzko H, Haberlandt W, Heilbronner H, Reill G, Weichardt $H$. Cytogenetische Untersuchungen an Trichloräthylen-Arbeitern. Arch Toxicol 1978;40: 201-6.

${ }^{127}$ Meretoja T, Vainio H, Sorsa M, Härkönen H. Occupational styrene exposure and chromosomal aberrations. Mutat Res 1977;56:193-7.

${ }^{128}$ Van Duuren BL. Carcinogenic epoxides, lactones and haloethers and their mode of action. Ann NY Acad Sci 1969;163:633-51.

129 Huang SL, Rader DN, Lee C-Y. The association between mutagenicity and adduct formation of 1,2,7,8diepoxyoctane and 1,2,5,6-diepoxycyclooctane. Chem
Biol Interact 1978;20:333-40.

${ }^{130}$ Henschler D, Bonse G. Metabolic activation of chlorinated ethylenes: dependence of mutagenic effect on electrophilic reactivity of the metabolically formed epoxides. Arch Toxicol 1977;39:7-12.

${ }^{131}$ Lehr RE, Yagi H, Thakker DR, et al. The bay region theory of polycyclic aromatic hydrocarbon-induced carcinogenicity. In: Jones PW, Freudenthal RI, eds. Carcinogenesis-a comprehensive survey. Vol 3 Polynuclear aromatic hydrocarbons. Second international symposium on analysis, chemistry and biology. New York: Raven Press, 1978:231-41.

${ }^{132}$ Hine $\mathrm{CH}$, Rowe VK. Epoxy compounds. In: Patty FA. Industrial hygiene and toxicology. Vol 11 Toxicology. 2nd ed. New York: Interscience, 1963:1593-1654.

${ }^{133}$ Smyth HF, Weil CS, Woodside MD, Knaak JB, Sullivan LJ, Carpenter CP. Experimental toxicity of a high molecular weight poly(ethylene oxide). Toxicol Appl Pharmacol 1970;16:442-5.

${ }^{134}$ Savolainen $\mathrm{H}$, Vainio H. Organ distribution and nervous system binding of styrene and styrene oxide. Toxicology $1977 ; 8: 135-41$.

${ }^{135}$ Ehrenberg L, Hiesche KD, Osterman-Golkar S, Wennberg I. Evaluation of genetic risks of alkylating agents: tissue doses in the mouse from air contaminated with ethylene oxide. Mutat Res 1974;24:83-103.

${ }^{136}$ Appelgren L-E, Eneroth G, Grant C. Studies on ethylene oxide-whole body autoradiography and dominant lethal test in mice. Proceedings of the European Society of Toxicology 1977;18:315-7.

137 Weigel WW, Plotnick HB, Conner WL. Tissue distribution and excretion of ${ }^{14} \mathrm{C}$-epichlorohydrin in male and female rats. Res Commun Chem Pathol Pharmacol 1978; 20:275-87.

${ }^{138}$ Oesch F. Mammalian epoxide hydrases: inducible enzymes catalysing the inactivation of carcinogenic and cytotoxic metabolites derived from aromatic and olefinic compounds. Xenobiotica 1973;3:305-40.

${ }^{139}$ Booth J, Hewer A, Keysell GR, Sims P. Enzymic reduction of aromatic hydrocarbon epoxides by the microsomal fraction of rat liver. Xenobiotica 1975;5:197-203.

140 Bend JR, Hook GER. Hepatic and extrahepatic mixedfunction oxidases. In: Lee DHK, Falk HL, Murphy SD, Greiger SR, eds. Handbook of Physiology Section 9Reactions to Environmental Agents. Bethesda, Maryland: American Physiological Society, 1977:419-40.

141 Jerina DM, Bend JR. Glutathione S-transferases. In: Jollow DJ, Kocsis JJ, Snyder R, Vainio H, eds. Biological reactive intermediates-formation, toxicity and inactivation. New York and London: Plenum Press, 1977: 207-36.

${ }^{1+2}$ Booth J, Sims P. 8,9-Dihydro-8,9-dihydroxybenz[a] anthracene 10,11-oxide. New type of polycyclic aromatic hydrocarbon metabolite. FEBS Lett 1974;47:30-3.

${ }^{113}$ Swaisland AJ, Hewer A, Pal K, et al. Polycyclic hydrocarbon epoxides. Involvement of 8,9-dihydro- 8,9dihydroxybenz(a)anthracene 10,11-oxide in reactions with the DNA of benz(a)anthracene treated hamster embryo cells. FEBS Lett 1974;47:34-8.

${ }^{144}$ Wislocki PG, Wood AW, Chang RL, et al. High mutagenicity and toxicity of a diol epoxide derived from benzo(a)pyrene. Biochem Biophys Res Commun 1976; 68:1006-12.

145 Oesch F. Purification and specificity of a human microsomal epoxide hydratase. Biochem $J$ 1974;139:77-88.

${ }^{116}$ Brookes P. Role of covalent binding in carcinogenicity. In: Jollow DJ, Kocsis JJ, Snyder R, Vainio H, eds. Biological reactive intermediates-formation, toxicity and inactivation. New York and London: Plenum Press, 1977:470-80. 
147 Lehmann AR, Bridges BA. DNA repair. In: Campbell PN, Aldridge WN, eds. Essays in biochemistry. Vol 13. London, New York: Academic Press, 1977:71-119.

${ }^{148}$ Frigerio A, Cavo-Briones M, Belvedere G. Formation of stable epoxides in the metabolism of tricyclic drugs. Drug Metab Rev 1976;5:197-218.

149 Brookes P, Lawley PD. Alkylating agents. Br Med Bull 1964;20:91-5.

150 Brookes P, Lawley PD. Evidence for the binding of polynuclear aromatic hydrocarbons to the nucleic acids of mouse skin: relation between carcinogenic power of hydrocarbons and their binding to deoxyribonucleic acid. Nature 1964;202:781-4.

151 Brookes P, Lawley PD. Reaction of some mutagenic and carcinogenic compounds with nucleic acids. Journal of Cellular and Comparative Physiology $1964 ; 64$, suppl I:111-28.

${ }^{152}$ Duncan M, Brookes P, Dipple A. Metabolism and binding to cellular macromolecules of a series of hydrocarbons by mouse embryo cells in culture. Int $J$ Cancer 1969;4:813-9.

${ }^{153}$ Duncan ME, Brookes P. Metabolism and macromolecular binding of dibenz[a,c]anthracene and dibenz[a,h] anthracene by mouse embryo cells in culture. Int $J$ Cancer 1972;9:349-52.

154 Buty SG, Thompson S, Slaga TJ. The role of epidermal hydrocarbon hydroxylase in the covalent binding of polycyclic hydrocarbon to DNA and its relationship to tumour initiation. Biochem Biophys Res Commun 1976; 70:1102-8.

${ }^{155}$ Ehrenberg L, Osterman-Golkar S, Segerbäck D, Svensson $\mathrm{K}$, Calleman CJ. Evaluation of genetic risks of alkylating agents. III Alkylation of haemoglobin after metabolic conversion of ethene to ethene oxide in vivo. Mutat Res 1977;45:175-84.

${ }^{156}$ Calleman CJ, Ehrenberg L, Jansson B, et al. Monitoring and risk assessment by means of alkyl groups in hemoglobin in persons occupationally exposed to ethylene oxide. J Environ Pathol Toxicol 1978;2:427-42.

157 Trosko JE, Chang C-C. Role of DNA repair in mutation and cancer production. In: Smith KC, ed. Aging, carcinogenesis and radiation biology. New York and London : Plenum Press, 1976:399-442.

${ }^{158}$ Strauss BS. Repair of DNA adducts produced by alkylation. In: Smith KC, ed. Aging, carcinogenesis and radiation biology. New York and London: Plenum Press, 1976:287-314.

159 Setlow RB. Repair deficient human disorders and cancer. Nature 1978;271:713-7.

${ }^{180}$ Kouri RE, Salerno RA, Whitmire CE. Relationships between aryl hydrocarbon hydroxylase inducibility and sensitivity to chemically induced subcutaneous sarcomas in various strains of mice. J Natl Cancer Inst 1973;50 363-8.

${ }^{161}$ Kellermann G, Luyten-Kellermann M, Shaw CR. Presence and induction of epoxide hydrase in cultured human leukocytes. Biochem Biophys Res Commun 1973; 52:712-6.

${ }^{162}$ Kellermann G, Shaw CR, Lutyen-Kellermann M. Aryl hydrocarbon hydroxylase inducibility and bronchogenic carcinoma. N Engl J Med 1973;289:934-7.

${ }^{163}$ Gelboin HV. Cancer susceptibility and carcinogen metabolism. N Engl J Med 1977;297:384-6.

${ }^{164}$ Moolten FL, Capparell NJ, Boger E, Mahathalang P.
Induction of antibodies against carcinogenic polycyclic aromatic hydrocarbons. Nature 1978;272:614-6.

165 Pachecka J, Salmona M, Cantoni L, et al. Activity of liver microsomal mono-oxygenases on some epoxideforming tricyclic drugs. I Kinetics in vitro. Xenobiotica 1976;6:593-8.

168 Frigerio A, Pantarotto C. Relationship between structure and metabolism of tricyclic drugs: stable epoxide-diol pathway. In: Frigerio A, Ghisalberti EL, eds. Mass spectrometry in drug metabolism. New York: Plenum Press, 1977:251-76.

167 Jori A, Salmona M, Cantoni L, Guiso G. Effect of contraceptive drugs on liver mono-oxygenases in several animal species. In: Garattini S, Berendes $\mathrm{HW}$, eds. Pharmacology of steroid contraceptive drugs. New York: Raven Press, 1977:313-75.

168 Pachecka J, Salmona M, Belvedere G, Cantoni L, Mussini E, Garattini S. Inhibition of liver microsomal epoxide hydrase by cyproheptadine epoxide. Experientia 1977;33:484-5.

${ }^{169}$ Salmona M, Pachecka J, Cantoni L, Belvedere G, Mussini E, Garratini S. Microsomal styrene monooxygenase and styrene epoxide hydrase activities in rats. Xenobiotica 1976;6:585-91.

170 Andersen ME, Jones RA, Jenkins LJ. Enhancement of 1,1 dichloroethylene toxicity by pretreatment of fasted male rats with 2,3-epoxypropan-1-o1. Drug Chem Toxicol 1977-8;1:63-74.

171 Thomson R, Kilroe-Smith TA, Webster I. The effect of asbestos-associated metal ions on the binding of benzo(a)pyrene to macromolecules in vitro. Environ Res 1978;15:309-19.

172 Bardoděj Z, Krivucová M, Pokorný F. Biochemical explanation of intolerance to alcohol in trichloroethylene intoxication. Pracovni Lékařství 1955; 7:263-7.

${ }^{173}$ Bardoděj Z, Vyskočil J. The problem of trichloroethylene in occupational medicine. Arch Ind Health 1956;13: $581-92$.

174 Windemuller FJB, Ettema JH. Effects of combined exposure to trichloroethylene and alcohol on mental capacity. Int Arch Occup Environ Health 1978;41:77-85.

175 Cornish HH, Adefuin J. Ethanol potentiation of halogenated aliphatic solvent toxicity. Am Ind Hyg Assoc J 1966;27:57-61.

176 Traiger GJ, Plaa GL. Chlorinated hydrocarbon toxicity. Potentiation of isopropyl alcohol and acetone. Arch Environ Health 1974;28:276-8.

177 Radike MJ, Stemmer KL, Brown PG, Larson E, Bingham E. Effect of ethanol and vinyl chloride on the induction of liver tumours: preliminary report. Environ Health Perspect 1977;21:153-5.

${ }^{178}$ More chemicals listed for TSCA testing. Chemical and Engineering News 1978 April 24: 6.

179 Fishbein L. Potential hazards of fumigant residues. Environ Health Perspect 1976;14:39-45.

180 Habig WH, Kamisaka K, Ketley JN, Pabst MJ, Arias IM, Jakoby WB. The human hepatic glutathione Stransferases. In: Arias IM, Jakoby WB, eds. Glutathione: metabolism and function. New York: Raven Press, 1976: 225-32.

${ }^{181}$ Osterman-Golkar S, Ehrenberg L, Segerbäck D, Hällström I. Evaluation of genetic risks of alkylating agents. II Haemoglobin as a dose monitor. Mutat Res 1976;34: 1-10. 